University of Nebraska - Lincoln

DigitalCommons@University of Nebraska - Lincoln

Relations between and among contaminant concentrations and biomarkers in black bass (Micropterus spp.) and common carp (Cyprinus carpio) from large U.S. rivers, 1995-2004

Jo Ellen Hinck

U.S. Geological Survey, Columbia Environmental Research Center, 4200 New Haven Rd., Columbia, MO

Christopher J. Schmitt

U.S. Geological Survey, Columbia Environmental Research Center, 4200 New Haven Rd., Columbia, MO, cjschmitt@usgs.gov

Mark R. Ellersieck

University of Missouri, EllersieckM@Missouri.edu

Donald E. Tillitt

U.S. Geological Survey, Columbia Environmental Research Center, 4200 New Haven Rd., Columbia, MO

Follow this and additional works at: https://digitalcommons.unl.edu/usgsstaffpub

Part of the Geology Commons, Oceanography and Atmospheric Sciences and Meteorology Commons, Other Earth Sciences Commons, and the Other Environmental Sciences Commons

Hinck, Jo Ellen; Schmitt, Christopher J.; Ellersieck, Mark R.; and Tillitt, Donald E., "Relations between and among contaminant concentrations and biomarkers in black bass (Micropterus spp.) and common carp (Cyprinus carpio) from large U.S. rivers, 1995-2004" (2008). USGS Staff -- Published Research. 878. https://digitalcommons.unl.edu/usgsstaffpub/878

This Article is brought to you for free and open access by the US Geological Survey at DigitalCommons@University of Nebraska - Lincoln. It has been accepted for inclusion in USGS Staff -- Published Research by an authorized administrator of DigitalCommons@University of Nebraska - Lincoln. 


\title{
Relations between and among contaminant concentrations and biomarkers in black bass (Micropterus spp.) and common carp (Cyprinus carpio) from large U.S. rivers, 1995-2004 $\dagger$
}

\author{
Jo Ellen Hinck, ${ }^{* a}$ Christopher J. Schmitt, $^{a}$ Mark R. Ellersieck ${ }^{b}$ and Donald E. Tillitt ${ }^{a}$ \\ Received 28th June 2008, Accepted 23rd September 2008 \\ First published as an Advance Article on the web 10th October 2008 \\ DOI: 10.1039/b811011e
}

Environmental contaminant and biomarker monitoring data from major U.S. river basins were summarized for black bass (Micropterus spp.) and common carp (Cyprinus carpio) sampled over a nine year period. Cumulative frequency distributions revealed taxon differences for many organochlorine residue concentrations, elemental contaminant concentrations, and biomarkers, but few gender differences were evident for chemical concentrations. Concentrations of dacthal, pentachloroanisole, $p, p^{\prime}$-DDE, endosulfan sulfate, barium, cadmium, copper, manganese, lead, selenium, vanadium, and zinc were greater in carp than bass, but concentrations of mercury and magnesium were greater in bass. Gender differences were evident in bass for mercury and in carp for zinc, but the differences were small compared to taxon differences. Greater vitellogenin concentrations, $17 \beta$-estradiol concentrations, $17 \beta$-estradiol/11-ketotestosterone ratios, and percent oocyte atresia in female carp compared to female bass may be related to the sequential spawning of carp. Regression analyses indicated that as much as $78 \%$ of biomarker variation was explained by chemical contaminant concentrations. Sites grouped consistently by river basin in the chemical contaminant principal components analysis (PCA) models and were driven by mercury, magnesium, barium, mirex, and oxychlordane. PCA models for the biomarkers did not group the sites by basin for either bass or carp. Statistical analyses and data interpretation were limited by the study design. The implications of these limitations are discussed. Recommendations to be considered during the planning of future monitoring studies include the exclusion of gender- and species-specific sampling for certain chemical contaminants considering analytical methods with appropriate sensitivities; and allowing for the addition of new chemical and biological variables as methods and information needs evolve.

\section{Introduction}

It is widely known that the health of fish and other aquatic organisms can be adversely affected by exposure to environmental contaminants. Exposure has been associated with adverse effects on development, growth, and reproduction. For example, selenium (Se) contamination has been associated with histopathological effects in the gill, liver, kidney, and ovary of freshwater fish, ${ }^{1}$ and dietary exposure to mercury $(\mathrm{Hg})$ can suppress hormone concentrations and inhibit gonadal development in female fish. ${ }^{2}$ Fish and other aquatic organisms are also important as vectors of contaminants such as $\mathrm{Hg}$ and $\mathrm{Se}$ to

${ }^{a}$ U.S. Geological Survey, Columbia Environmental Research Center, 4200 New Haven Rd., Columbia, MO 65201, USA

${ }^{b}$ Department of Statistics, University of Missouri, 146 Middlebush Hall, Columbia, MO, 65211, USA

$\dagger$ Electronic supplementary information (ESI) available: Table S1, collection sites and sample sizes for female and male bass and carp; Table S2, limits of detection for organochlorine residues, TCDD-EQ, and elemental contaminants; Table S3, cumulative frequency percentile concentrations of organochlorine chemical residues, TCDD-EQ, and elemental contaminants in whole-body fish composite samples; Table S4, cumulative frequency percentiles of biomarkers in individual fish. See DOI: $10.1039 / \mathrm{b} 811011 \mathrm{e}$ higher trophic levels (i.e., reptiles, birds, and mammals) and in the biotransportation of contaminants such as polychlorinated biphenyls (PCBs), organochlorine pesticides, and methylmercury along migration pathways. ${ }^{3}$

Studies that rely exclusively on conventional analytical measurements of chemical contaminants in biota to assess exposure provide little information about contaminants that do not bioaccumulate. These include most herbicides, phthalates, the most toxic polycyclic aromatic hydrocarbons (PAHs), pharmaceutical and personal care products, and organophosphate, carbamate, and synthetic pyrethroid insecticides. Chemical analysis alone also fails to account for the cumulative effects of multiple contaminants and other environmental factors. Biomarkers consequently have been incorporated into numerous laboratory and field studies to address some of these shortcomings. Biomarkers are physiological, biochemical, or histopathological changes that occur as a result of exposure to environmental contaminants. ${ }^{4}$ The use of biomarkers complements conventional analytical chemistry data by providing information on the biological effects of contaminants rather than simple quantification of their environmental concentrations. ${ }^{5}$ Many biomarkers respond to contaminants that do not bioaccumulate, and their response is cumulative over all environmental exposures and time. Biomarkers are typically less 
costly to implement than chemical analyses; they can be used as screening tools in a tiered application to assess exposure before employing more expensive analytical methods. Biomarkers also span multiple levels of biological organization, from sub-cellular to whole organism, and can be contaminant-specific or broad indicators of organism health. Some biomarkers respond rapidly to contaminant exposure at the molecular, organelle, and organism level, and therefore represent earlier indicators of exposure than contaminant accumulation. Biochemical and physiological parameters are typically used to document sub-organelle changes, whereas morphological parameters are higher-level responses that may indicate irreversible damage. ${ }^{6}$ Nevertheless, biomarkers have limitations; most are indicators of exposure rather than effects, and they may vary depending on species, gender, age, diet, reproductive status, and other factors. ${ }^{5}$ Therefore, cause-effect relationships between contaminant exposure and biomarker responses are difficult to determine in field studies. ${ }^{7}$

Although biomarkers are routinely employed in localized investigations, their use in large-scale (i.e., river basin, regional, national) environmental monitoring has been limited to primarily estuarine and marine systems. For example, the Bioeffects Assessment Project conducts studies using sediment toxicity surveys and biomarkers to describe the conditions of coastal ecosystems, ${ }^{8}$ and the Estuaries Program of the Environmental Monitoring and Assessment Program has incorporated histological biomarkers in contaminant studies. ${ }^{9}$ The National Benthic Surveillance Project used biomarkers to examine the health of English sole (Parophyrus vetulus) on the Pacific coast of the United States. ${ }^{10,11}$ In addition, the European Biological Effects of Environmental Pollution in Marine Coastal Ecosystems (BEEP Project) was designed to validate a set of biomarkers for use in marine biomonitoring and ecological risk assessment. ${ }^{\mathbf{1 2}}$ Biomarkers have also been used to assess contaminant exposure in various fish species in the North Sea. ${ }^{13,14}$ Concentrations of chemical contaminants and biomarkers (fish health indicators and reproductive endpoints) were measured in piscivorous and benthivorous fish collected in 1995-2004 from large U.S. river basins as part of the Biomonitoring of Environmental Status and Trends (BEST) Program. ${ }^{15-19}$ The methods used by the BEST Program were selected to maximize sensitivity, cost-effectiveness, and the variety of contaminants and their effects that could be detected with minimal redundancy using methods that were readily available in $1995 .{ }^{15}$ Results of individual studies indicated correlations between chemical contaminants and biomarkers, but more rigorous statistical analyses were precluded by the limited number of samples from each basin. Here we report the results of more in-depth analyses of these data from the sampled basins. We examined relations among and between contaminant concentrations and biomarkers in black bass (Micropterus spp.; bass) and common carp (Cyprinus carpio; carp), the most frequently collected taxa. Our objectives were to (1) determine the frequency distribution of contaminant concentrations and biomarkers; (2) examine the statistical relations between and among contaminant concentrations and biomarkers using stepwise multiple regression and multivariate analysis; and (3) evaluate the utility of the chemical and biomarkers in monitoring studies.

\section{Materials and methods}

Details of the sampling, field, and laboratory procedures have been described previously. ${ }^{15-19}$ A brief summary is presented here. All data are accessible at www.cerc.usgs.gov/data/best/ search/index.htm.

\section{Collection sites and field procedures}

Bass $(n=1003)$ and carp $(n=1605)$ were collected from 96 sites on major U.S. rivers (Fig. 1). Sites were located in the Apalachicola-Chattahoochee-Flint River basin (ARB, 3 sites), Colorado River basin (CORB, 14 sites), Columbia River basin (CRB, 11 sites), Mobile River basin (MORB, 4 sites), Mississippi River basin (MRB, 48 sites), Pee Dee River basin (PRB, 3 sites), Rio Grande basin (RGB, 10 sites), and Savannah River basin (SRB, 3 sites; ESI, Table S1†). Capture method was typically electrofishing. The collection target at each site was 10 (each) adult male and female bass and carp of similar length and weight. Fish were held in aerated live-wells or net pens until processed (usually less than three hours).

A field necropsy was performed on each fish. Briefly, a blood sample, obtained from the caudal artery with a heparinized needle and syringe, was centrifuged, and the plasma was aspirated and frozen in dry ice for vitellogenin and sex steroid hormone analyses. The fish was then weighed, measured, and killed with a blow to the head. The abdominal cavity was dissected open to permit observation of the internal organs. The gender of the fish along with observations of external and internal features were recorded. The liver (bass only; carp have a dispersed liver), spleen, and gonads were removed and weighed. Pieces of liver were collected and immediately frozen in a dry ice and ethanol slurry, then transferred in dry ice or liquid nitrogen ice for analysis of ethoxyresorufin $O$-deethylase (EROD) activity. Samples of spleen and gonad were obtained and preserved in $10 \%$ neutral buffered formalin for histopathological examination. Scales or otoliths were collected for age determination. All remaining tissues (those not frozen or fixed) were wrapped in aluminium foil and frozen for chemical analysis.

\section{Laboratory analyses}

Analytical chemistry. Whole-body composite samples were shipped to the laboratory frozen and stored at $-20{ }^{\circ} \mathrm{C}$ until prepared for analysis. Individual fish were partly thawed, cut into pieces, and ground to a fine texture. The ground fish were then mixed together to create a single homogenous composite sample for each site, species, and gender combination (307 samples). Details of the analytical methods and quality assurance/quality control (QA/QC) procedures are described in the original studies. ${ }^{15,16,17,18,19}$ Chemical methods were sufficiently low to detect exposure of the fish to biologically relevant (i.e., toxic) concentrations of contaminants based on contemporaneous information.

One sub-sample (10 g) of each composite sample was solventextracted and analysed gravimetrically for lipid content and by high-resolution capillary gas chromatography with electron capture detection (GC-ECD) for organochlorine chemical residues and total PCBs after size exclusion and adsorption column cleanup procedures. Pentachlorobenzene, pentachloroanisole, 


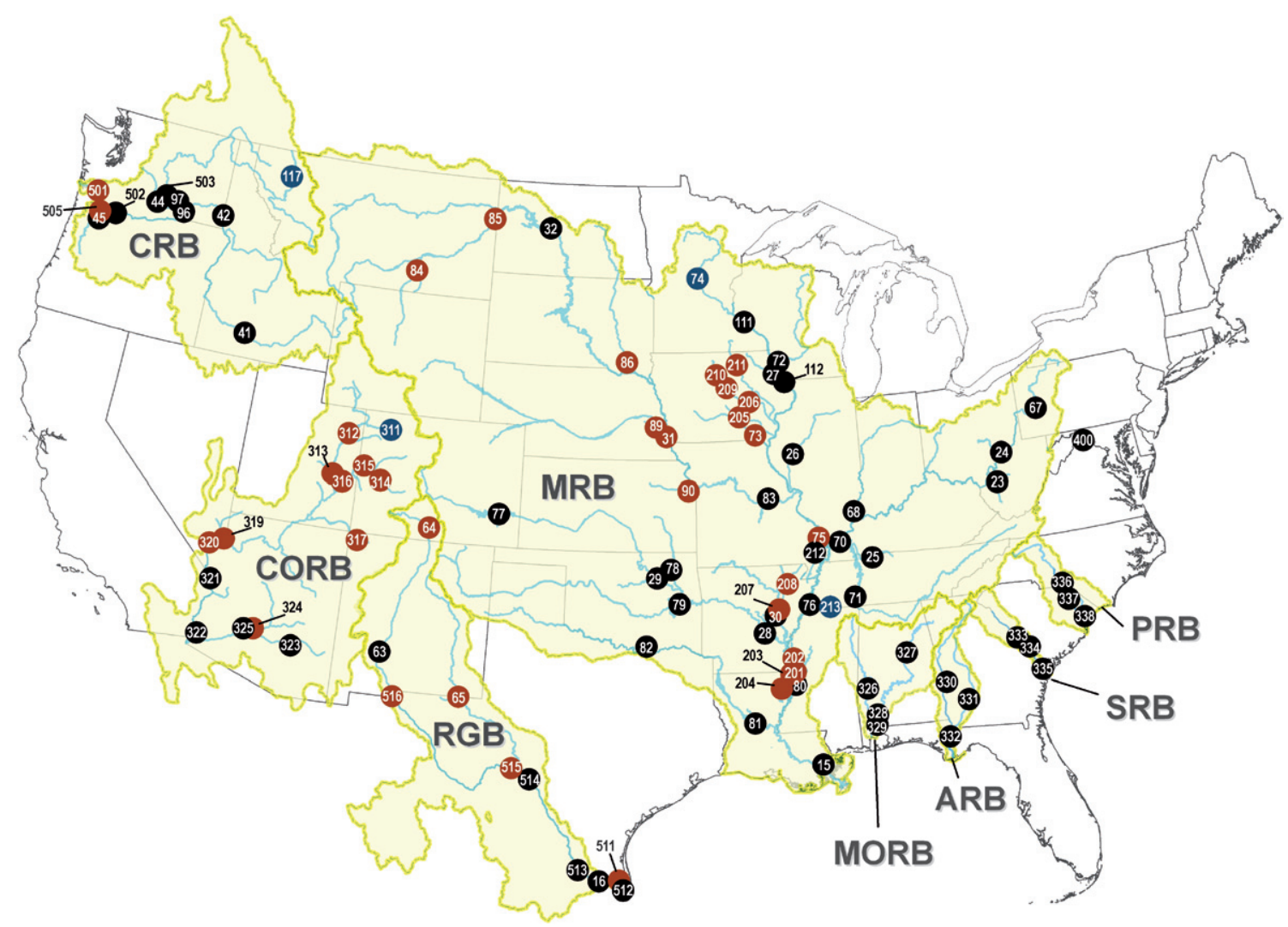

Fig. 1 Map showing sampling sites in the Columbia River basin (CRB), Colorado River basin (CORB), Rio Grande basin (RGB), Mississippi River basin (MRB), Mobile River basin (MORB), Apalachicola River basin (ARB), Savannah River basin (SRB), and Pee Dee River basin (PRB). Black circles, carp and bass collected; Red circles, carp only; Blue circles, bass only. Site numbers are given within the circles. See Table S1 for specific site information. $\dagger$

aldrin, dacthal, heptachlor, endosulfan I, endosulfan II, endosulfan sulfate, and methoxychlor were not measured in samples from the MRB, RGB, or CRB. QC measures for the organochlorine pesticide and $\mathrm{PCB}$ analyses included the analysis of blanks, triplicate analyses, and matrix spikes. The limit of detection (LOD) was calculated by adding the procedural blank concentration to three times the procedural blank standard deviation. LODs for organochlorines varied among study years; LODs decreased by two orders of magnitude for some organochlorine residues (ESI, Table $\mathrm{S} 2 \dagger$ ).

A second composite sub-sample (100 g) was freeze-dried for elemental analysis. Percent moisture was determined as weight lost during lyophilization. Sub-samples from the MRB, RGB, and CRB were acid-digested and analysed by atomic absorption spectroscopy for arsenic (As), lead $(\mathrm{Pb})$, and $\mathrm{Se}$ and by inductively coupled plasma emission spectroscopy for other elements. The sub-samples from the CORB, MORB, ARB, PRB, and SRB were analysed in three portions. Portion one was digested in nitric acid and analysed by inductively coupled plasma mass spectroscopy for barium $(\mathrm{Ba})$, cadmium $(\mathrm{Cd})$, copper $(\mathrm{Cu})$, chromium $(\mathrm{Cr})$, magnesium $(\mathrm{Mg})$, manganese $(\mathrm{Mn})$, molybdenum (Mo), nickel (Ni), Pb, strontium (Sr), vanadium (V), and zinc $(\mathrm{Zn})$. Portion two was dry-ashed (magnesium nitrate-nitric acid- $\mathrm{HCl}$ ) and analysed by hydride generation atomic absorption spectroscopy for As and Se. Portion three was analysed directly for total $\mathrm{Hg}$ using thermal combustion, amalgamation, and atomic absorption spectroscopy. QC measures for the elemental analyses included the analysis of reagent blanks, duplicate samples, certified reference materials, and fortified samples. Dry-weight LODs were determined for each element in individual samples and converted to wet weight values for statistical analysis and reporting (ESI, Table $\mathrm{S} 2 \dagger$ ).

A third composite sub-sample (10 g) was solvent-extracted and subjected to reactive cleanup for use in the H4IIE bioassay. ${ }^{20}$ Concentrations of 2,3,7,8-tetrachlorodibenzo- $p$-dioxin equivalent doses (TCDD-EQ; g g $^{-1}$ wet weight) were determined by slope ratio assay. ${ }^{21} \mathrm{QC}$ measures for the H4IIE bioassay included determination of LODs and analysis of duplicate samples and reference materials.

A combination of biological and chemical methods was used for evaluating planar halogenated hydrocarbons (PHHs) and PAHs that did not involve high-resolution instrumental analyses. ${ }^{15}$ As previously described, total PCBs were analysed by GC-ECD, and the H4IIE bioassay provided semi-quantitative information on the cumulative concentration of aryl hydrocarbon hydroxylase-active PCBs, chlorodibenzo-p-dioxins, chlorodibenzofurans, and related compounds of concern ${ }^{20}$ and augments the information on total PCBs provided by the instrumental analysis of the composite samples. Hepatic EROD activity in the fish can be induced by PHHs as well as by PAHs and other compounds that were removed from the composite sample extracts by the reactive cleanup. ${ }^{22}$ Consequently, hepatic 
EROD activity documents the cumulative exposure of the fish to all AHH-active compounds, including the PAHs and other labile compounds that would not otherwise be accounted for by instrumental analysis or the H4IIE bioassay with reactive cleanup.

Biomarkers. Criteria for biomarker selection included: (1) the method was well documented in the peer-reviewed scientific literature; (2) the method had been correlated with contaminant exposure, other stressors, or both across a gradient and yielded reproducible and verifiable results; (3) its performance had been documented statistically; (4) it was able to detect relevant differences (spatial, temporal, etc.) at desired significance level $(p<0.05)$ with financially realistic sample sizes and sampling frequencies; (5) confounding or interfering variables that affect performance were known; and (6) the methods had been documented in the scientific literature in the species for which its use was proposed. ${ }^{23}$

Biomarkers measured in individual fish included total length, weight, age, condition factor, hepatosomatic index, splenosomatic index, macrophage aggregate (MA) parameters, health assessment index, reproductive biomarkers (gonadosomatic index, plasma vitellogenin concentration, plasma sex steroid hormone concentrations, and oocyte atresia), and hepatic EROD activity. Hepatic EROD activity was determined on microsomal fractions from individual fish with protein content quantified using the fluorescamine protein assay. ${ }^{22,24} \mathrm{QC}$ measures included determination of LODs (0.01-3.76 pmol $\left.\mathrm{min}^{-1} \mathrm{mg}^{-1}\right)$ and the analysis of reference materials and duplicate samples. Body and organ weights were used to compute condition factor, hepatosomatic index, splenosomatic index, and gonadosomatic index according to the following formulae: condition factor $=$ body weight in $\mathrm{g}$ (length in $\mathrm{cm})^{-3}$; hepatosomatic index $=$ liver weight/ (total body weight - gonad weight)100; splenosomatic index = spleen weight/(total body weight - gonad weight)100; gonadosomatic index $=($ gonad weight/total body weight $) 100$. The weight of the gonads was subtracted from the body weight to minimize the effect of the reproductive cycle on hepatosomatic index and splenosomatic index. A necropsy-based health assessment index score was calculated for each fish by assigning numerical values to gross lesions of various organs, then summing the values for all organs observed. A health assessment index score, which can range from 0 (good health) to 220 (poor health), was computed for a fish only if observations were made for all components.

Preserved tissue samples were prepared for reproductive stage determination (gonad) and MA analysis (spleen). Transverse ovary sections were assigned to reproductive stages $0-5$ based on the predominant size and appearance of oocytes, and transverse testes sections were similarly classified into reproductive stages $0-4$. Atresia was quantified by examining one hundred oocytes in each sample. MAs in spleen sections were quantified using computer-based image or manually digitized microscopic analyses. MA parameters included the number of aggregates in $2 \mathrm{sq}$. mm of tissue (MA-\#) and the mean size (area) of aggregates within those 2 sq. mm (MA-A). The percentage of the tissue area occupied by aggregates (MA-\%) was computed from these measurements. Concentrations of vitellogenin were determined by direct enzyme-linked immunosorbent assay and were reported as the mean of triplicate measurements. Concentrations of sex steroid hormones including $17 \beta$-estradiol and 11-ketotestosterone in plasma samples were measured by radioimmunoassay. QC measurements for these analyses included determination of LODs, coefficients of variation, and inter-assay variability.

\section{Statistical analyses}

Version 9.1 of SAS (Cary, NC) was used for al statistical analyses. Arithmetic means and standard errors were used to simplify the tabular presentation; $\log _{10}$ transformed data (e.g., geometric means) were used for all other statistical analyses. Censored values (those $<$ LOD) for chemical concentrations, EROD activity, and vitellogenin concentrations were replaced by one half the LOD in all statistical analyses. Summary statistics are presented for the reproductive biomarkers by maturational stage because their responses vary over the reproductive cycle of fish. Taxa and gender differences in chemical concentrations and biomarkers for sites where female and male bass and carp were collected $(n=51$; ESI, Table S1 $\dagger$ ) were tested with two-way analysis-of-variance (ANOVA) using Fisher's unrestricted least significant difference to separate means $(p<0.05){ }^{25}$ All text describing these ANOVA results refers to this subset of sites even though the figures depict cumulative frequency distributions for all sites.

Exploratory data analyses were conducted to examine and characterize relations between and among chemical endpoints and biomarkers in bass and carp using stepwise multiple linear regression and principal components analysis (PCA). The latter reduced the number of variables to smaller numbers of principal components (PCs). Biomarker means, based only on those individual fish included in each composite sample, were computed and paired with contaminant concentrations in composite samples for these analyses. Multiple regression analyses were conducted with PROC REG. The forward selection method was used, and variables were allowed into the model only if they significantly $(p<0.05)$ reduced the unexplained sum-of-squares after accounting for all other factors (i.e., the type-II sums-ofsquares were used). Separate regression models were developed and evaluated for males and females of each taxon. The reproductive biomarkers were analysed as reduced-rank data sets restricted to the predominant reproductive stages in bass (stages 1 and 2) and carp (stages 2 and 3). Additional regression analyses were conducted to examine relations among hepatic EROD activity, total PCB, and TCDD-EQ concentrations. Prior to the PCA, correlations between chemical and biological endpoints were determined with Spearman rank correlation coefficients. Few correlations were significant for either bass or carp $(p<0.10$; data not shown); therefore, correlation analysis was not used to exclude endpoints in the PCA, which was performed with the PROC FACTOR procedure. Chemical and biological endpoints were analysed separately and as a combined data set in the PCA. Chemical endpoints were analysed with the taxon and genders combined (all fish), by taxon with the genders combined (all bass, all carp), and separately for each taxon-gender. Analyses of the biomarkers and combined chemical and biological data sets were conducted separately for each taxon-gender combination because of the influence of gender on the reproductive biomarkers. PCs greater than one were considered significant in the models. ${ }^{26}$ The first two PCs were used to generate factor scores for plotting purposes, which were calculated using PROC 
SCORES and were plotted using Version 10 of Sigma Plot (Systat Software, Inc., San Jose, CA). Organochlorine concentrations less than the maximum LOD (generally $10 \mathrm{ng} \mathrm{g}^{-1} ; 50 \mathrm{ng} \mathrm{g}^{-1}$ for total PCBs and toxaphene) were assigned a value of one-half the maximum LOD (generally $5 \mathrm{ng} \mathrm{g}^{-1} ; 25 \mathrm{ng} \mathrm{g}^{-1}$ for total PCBs and toxaphene) after initial PCA determined that the temporal differences in LODs were influencing the models.

Organochlorine residues were excluded from the regression and PC analyses if $\leq 10$ samples exceeded the LOD or they were not measured in all samples. These included pentachlorobenzene, pentachloroanisole, $\alpha$-hexachlorocyclohexane $(\mathrm{HCH}), \beta-\mathrm{HCH}$, $\gamma-\mathrm{HCH}, \delta-\mathrm{HCH}$, aldrin, endrin, dacthal, heptachlor, $o, p^{\prime}$-DDT, endosulfans, methoxychlor, and $\mathrm{Cd}$ for bass; and pentachlorobenzene, pentachloroanisole, $\gamma-\mathrm{HCH}, \delta-\mathrm{HCH}$, aldrin, dacthal, heptachlor, $o, p^{\prime}$-DDT, endosulfans, and methoxychlor for carp. 17 $\beta$-estradiol and 11-ketotestosterone were excluded from the analyses because they were not measured in fish from the RGB or CRB. Hepatosomatic index was excluded from the carp models because liver weight was not determined, and oocyte atresia can only be measured in female fish.

\section{Results}

\section{Summary statistics}

Organochlorine and elemental concentrations. The most frequently detected organochlorine chemical residues in bass and carp were dieldrin, cis-chlordane, cis-nonachlor, trans-nonachlor, $p, p^{\prime}$-DDE, $p, p^{\prime}$-DDD, total PCBs, and TCDD-EQ (Table 1). Concentrations of most organochlorine residues were low and similar in bass and carp. Overall, median concentrations of most residues in female and male bass and carp were $\leq 5.00 \mathrm{ng} \mathrm{g}^{-1}$ (Table 1; Fig. 2); however, some medians were influenced by the comparatively high LOD (10.0 $\left.\mathrm{ng} \mathrm{g}^{-1}\right)$ of samples from the MRB, RGB, and CRB (ESI, Table S2 $\dagger$ ). Mean concentrations in female and male bass were greatest for trans-nonachlor, $p, p^{\prime}$-DDE, $p, p^{\prime}$ DDD, $p, p^{\prime}$-DDT, total PCBs, and toxaphene (Table 1). Mean concentrations in female and male carp were greatest for $p, p^{\prime}-$ DDE, total PCBs, toxaphene, $p, p^{\prime}$-DDD, dieldrin, trans-nonachlor, $o, p^{\prime}$-DDD, endrin, cis-chlordane (Table 1).

Differences between carp and bass were evident in the cumulative frequency distributions of dacthal, pentachloroanisole, $p, p^{\prime}$-DDE, and endosulfan sulfate concentrations, but differences between genders were not evident in either taxon (Fig. 2; ESI, Table S3 $\dagger$ ). At sites where both taxa were collected, concentrations of pentachloroanisole $\left(F_{1,64}=65.03\right)$, cis-chlordane $\left(F_{1,200}\right.$ $=5.45)$, trans-chlordane $\left(F_{1,200}=8.29\right), p, p^{\prime}$-DDT $\left(F_{1,200}=\right.$ $7.70)$, and endosulfan sulfate $\left(F_{1,64}=10.49\right)$ were significantly greater in carp than bass.

All elemental contaminant concentrations except $\mathrm{Cd}$ in bass and Mo and V in bass and carp were > LOD in most samples (Table 1). The cumulative frequency percentiles of female and male fish generally were similar within each taxon (ESI, Table $\mathrm{S} 3 \dagger)$, but median and mean concentrations of some elemental contaminants differed between bass and carp. Concentrations of $\mathrm{Ba}, \mathrm{Cd}, \mathrm{Cu}, \mathrm{Mn}, \mathrm{Pb}, \mathrm{Se}, \mathrm{V}$, and $\mathrm{Zn}$ were greater in carp than bass, whereas concentrations of $\mathrm{Hg}$ and $\mathrm{Mg}$ were greater in bass (Fig. 3). At sites where both taxa were collected, these differences were significant for $\mathrm{Ba}\left(F_{1,200}=154.10\right), \mathrm{Cu}\left(F_{1,200}=389.89\right), \mathrm{Hg}$
$\left(F_{1,200}=68.58\right), \operatorname{Mg}\left(F_{1,200}=72.54\right), \operatorname{Mn}\left(F_{1,200}=193.46\right), \mathrm{Pb}$ $\left(F_{1,200}=41.83\right)$, Se $\left(F_{1,200}=9.19\right)$, and $\mathrm{Zn}\left(F_{1,200}=1771.29\right)$.

Biomarkers. Differences between taxa and genders were evident in the cumulative frequency percentiles of most biomarkers. At sites where both taxa were collected, these differences were significant $(p<0.05)$ for length $\left(F_{1,199}=367.90\right)$, weight $\left(F_{1,199}=\right.$ $308.00)$, condition factor $\left(F_{1,199}=3.94\right)$, age $\left(F_{1,198}=54.75\right)$, splenosomatic index $\left(F_{1,196}=298.89\right), \operatorname{EROD}\left(F_{1,196}=278.72\right)$, MA-\# $\left(F_{1,199}=4.05\right)$, MA- $\%\left(F_{1,199}=4.89\right)$, and health assessment index $\left(F_{1,197}=50.98\right)$. Median and maximum length, weight, age, splenosomatic index, MA-\#, and MA- $\%$ were greater in carp than bass (Table 2; ESI, Table S4†). Median condition factor and health assessment index scores were greater in bass than carp (Table 2; Table S4). Median EROD activity was four times greater in bass than carp, but maximum activity was similar in both taxa (Table 2; Table S4).

In contrast to the contaminant concentrations, gender differences were evident for some biomarkers in both taxa. Median length and weight were greater in female bass than male bass, but maximum values were similar between genders (Table 2; ESI, Table $\mathrm{S} 4 \dagger$ ). In carp, median length, weight, age, and MA-A were greater and median splenosomatic index, MA-\#, MA- $\%$ and EROD activity were lower in females than males (Table 2). At sites where both taxa were collected, gender differences were only significant for splenosomatic index $\left(F_{1,196}=4.30\right)$ and EROD $\left(F_{1,196}=12.64\right)$.

Reproductive biomarkers differed between taxa and genders and conformed to expected trends. At sites where both taxa were collected, taxa differences were significant for oocyte atresia $\left(F_{1,103}=32.41\right)$, gonadosomatic index $\left(F_{1,196}=1487.97\right)$, vitellogenin $\left(F_{1,196}=77.83\right), 17 \beta$-estradiol $\left(F_{1,155}=5.95\right)$, and $17 \beta$ estradiol/11-ketotestosterone $(\mathrm{E} / \mathrm{KT})$ ratio $\left(F_{1,155}=4698.28\right)$. Taxa-gender interactions were significant for vitellogenin $\left(F_{1,196}\right.$ $=36.45)$ and $\mathrm{E} / \mathrm{KT}$ ratio $\left(F_{1,155}=13.65\right)$. Gonadosomatic index and oocyte atresia (females only) were greater in carp than bass (Fig. 4). Gonadosomatic indices were significantly greater in females than males of both taxa $\left(F_{1,196}=130.96\right)$, which is probably because of the greater mass associated with eggs than milt (Table 3). Vitellogenin concentrations $\left(F_{1,196}=398.66\right), 17 \beta$ estradiol concentrations $\left(F_{1,155}=61.17\right)$, and $\mathrm{E} / \mathrm{KT}$ ratios $\left(F_{1,155}\right.$ $=152.13)$ were greater in female than male bass and carp, and these endpoints were greater in more reproductively advanced females and males of both taxa (Table 3; Fig. 4). The shape of the cumulative frequency distribution illustrates that vitellogenin concentrations were more frequently $<$ LOD in bass than carp (Fig. 4). In bass, vitellogenin concentrations were < LOD (0.001$0.005 \mathrm{mg} \mathrm{mL}^{-1}$ ) in $34 \%$ of females and $82 \%$ of males; vitellogenin concentrations were < LOD $\left(0.0005-0.005 \mathrm{mg} \mathrm{mL}^{-1}\right)$ in only $4 \%$ of female carp and $70 \%$ of male carp. Concentrations of 11-ketotestosterone did not increase with reproductive stage in males of either taxon (Table 3). The cumulative frequency distributions of the $\mathrm{E} / \mathrm{KT}$ ratio in male bass and carp were essentially identical, with few ratios $>1.0$ (Fig. 4).

\section{Regression analysis}

Statistically significant regression models of hepatosomatic index, splenosomatic index, condition factor, health assessment 


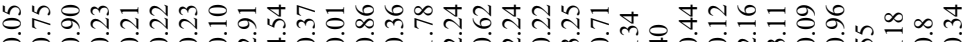

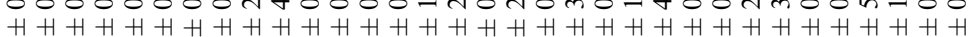

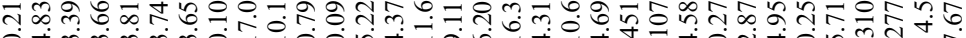

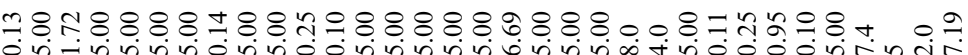

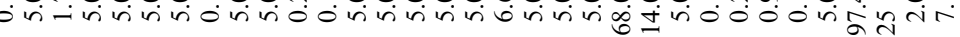

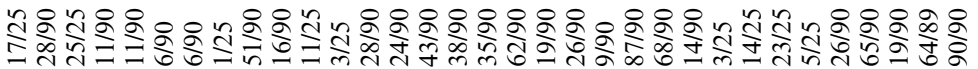

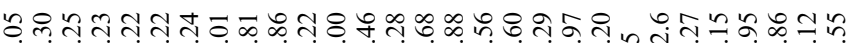

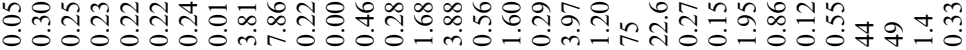

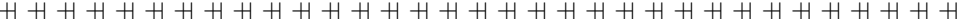

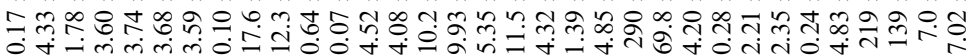

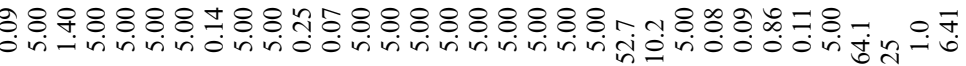

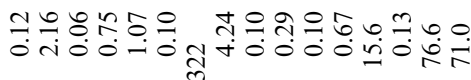

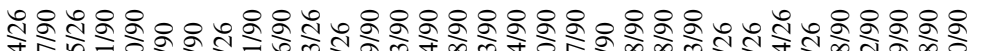

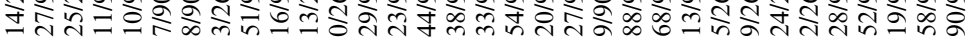

రૈกี

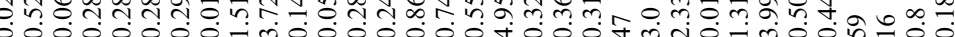
$H+H+H+H+H+H+H+H+H+H+H+H+H+H+H+H H+H+H+H+H+H$ \&

ำ $H+H+H+H H H+H+H H H+H+H$

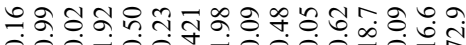

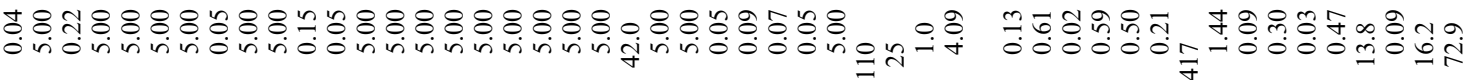

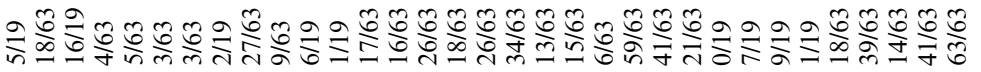

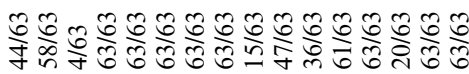

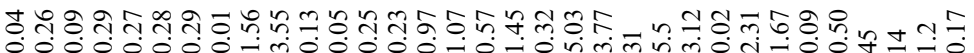
$H+H+H+H+H+H+H+H+H+H+H+H+H+H+H+H+H+H+H+H+H$

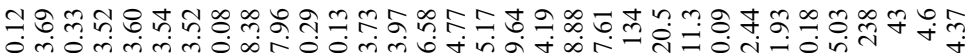

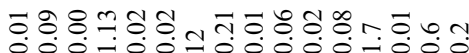
$H+H+H+H+H+H+H+H+H+H+H$

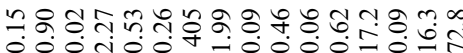

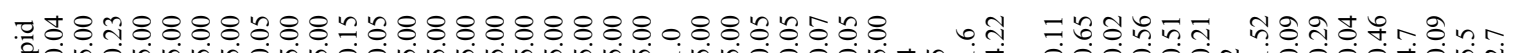

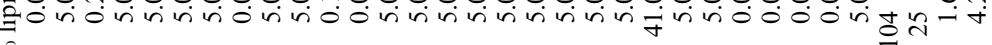
ฮ

过

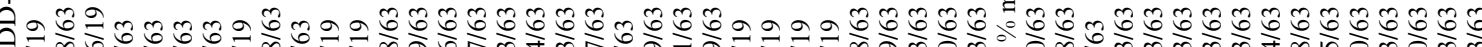

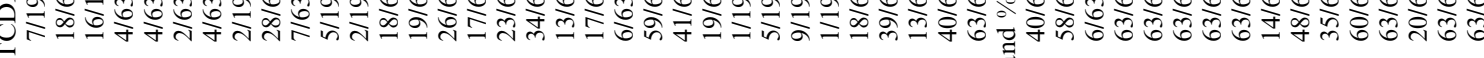

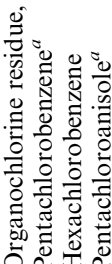

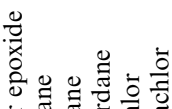

苞

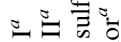



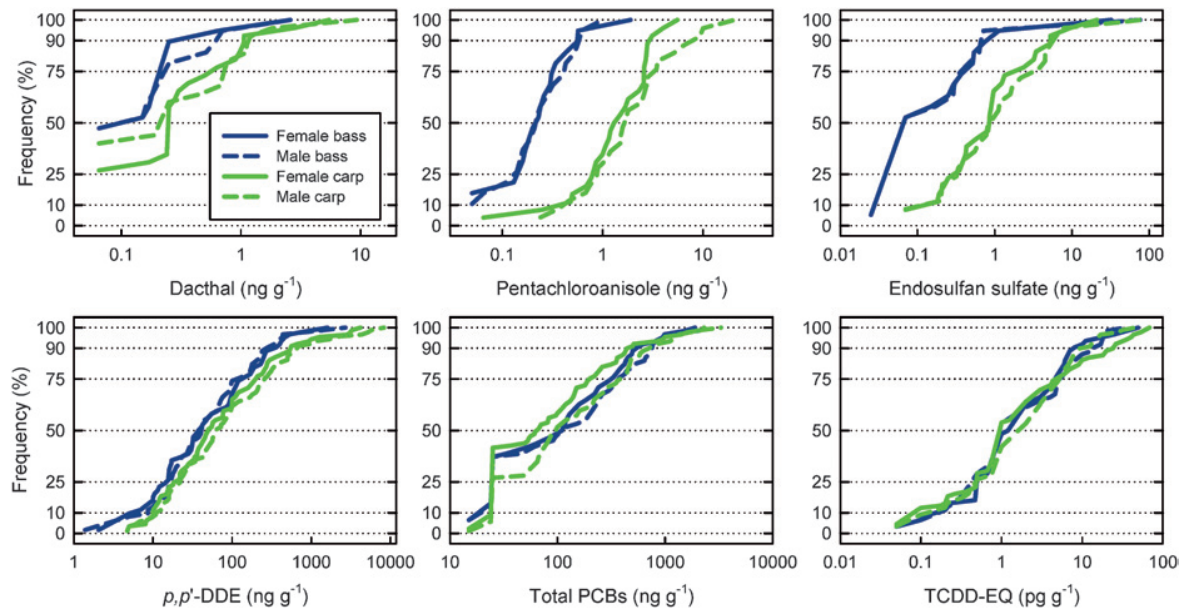

Fig. 2 Cumulative frequency distributions of organochlorine residue concentrations in bass and carp. Pentachloroanisole, dacthal, and endosulfan sulfate were not measured in samples from the Mississippi, Rio Grande, or Columbia River basins.
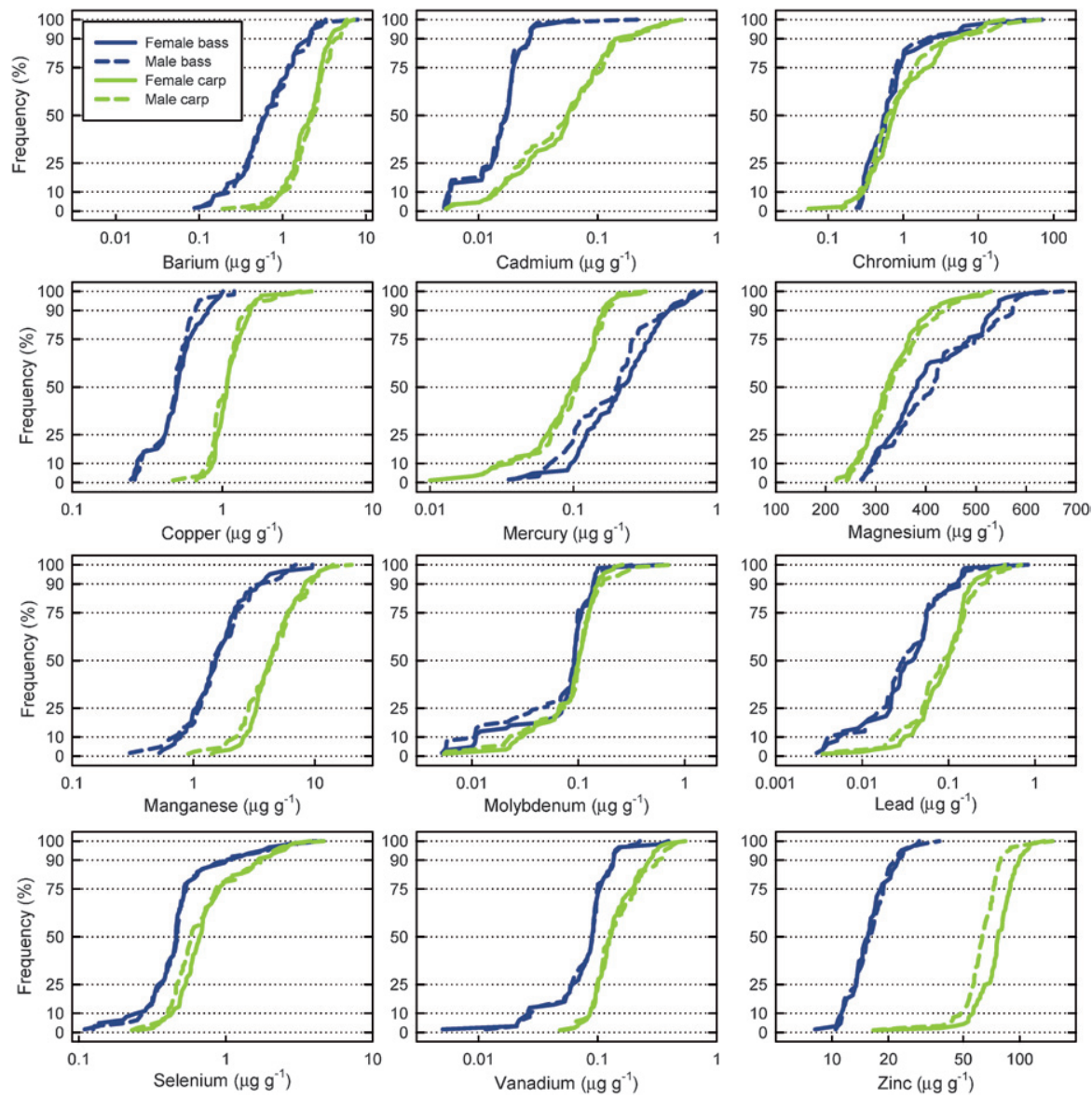

Fig. 3 Cumulative frequency distributions of elemental contaminant concentrations in bass and carp.

index, MA parameters, and hepatic EROD activity as functions of contaminant concentrations explained $10-64 \%$ of the total variation in bass and $24-77 \%$ in carp (Table 4). Models for some of the fish health indicators had common variables. The models for MA-A in carp explained less total variation than those for the MA-\# and MA-\%. However, similar to condition factor and the somatic indices, few variables were consistently significant among the MA models in either taxon. Mercury was significantly positive and $\mathrm{Zn}$ was negative in all bass models, and total PCBs and $\mathrm{Sr}$ were significantly positive in all the carp models for EROD (Table 4). Regressions describing hepatic EROD activity as functions of total PCB and TCDD-EQ concentrations were statistically significant in female and male carp but not bass. Although significant, the relations were weak in carp; they 
Table 2 Biomarkers in bass and carp. Shown are sample size (n), median, arithmetic mean, and standard error (SE)

\begin{tabular}{|c|c|c|c|c|c|c|}
\hline Taxon and endpoint & \multicolumn{3}{|c|}{ Female } & \multicolumn{3}{|c|}{ Male } \\
\hline Length $/ \mathrm{mm}$ & 531 & 351 & $362 \pm 3$ & 471 & 330 & $335 \pm 3$ \\
\hline Weight/g & 532 & 630 & $788 \pm 25$ & 471 & 500 & $584 \pm 16$ \\
\hline Age/years & 512 & 3 & $3.5 \pm 0.1$ & 457 & 3 & $3.1 \pm 0.1$ \\
\hline $\mathrm{EROD} / \mathrm{pmol} \mathrm{min}^{-1} \mathrm{mg}^{-1} a$ & 515 & 16.8 & $27.7 \pm 1.3$ & 448 & 21.7 & $32.4 \pm 1.5$ \\
\hline Splenosomatic index $(\%)$ & 522 & 0.100 & $0.127 \pm 0.004$ & 457 & 0.100 & $0.130 \pm 0.005$ \\
\hline $\mathrm{MA}-\mathrm{A} / \mu \mathrm{m}^{2}$ & 517 & 2891 & $3354 \pm 104$ & 460 & 2907 & $3448 \pm 112$ \\
\hline MA-\#/MA sq. $\mathrm{mm}^{-1}$ & 517 & 4.71 & $5.45 \pm 0.18$ & 460 & 4.71 & $5.27 \pm 0.17$ \\
\hline MA- $\%(\%)$ & 517 & 1.41 & $1.94 \pm 0.08$ & 460 & 1.48 & $2.01 \pm 0.09$ \\
\hline Health assessment index & 527 & 60 & $60 \pm 2$ & 463 & 60 & $56 \pm 2$ \\
\hline \multicolumn{7}{|l|}{ Carp } \\
\hline Length $/ \mathrm{mm}$ & 805 & 505 & $517 \pm 4$ & 796 & 490 & $494 \pm 3$ \\
\hline Splenosomatic index (\%) & 779 & 0.230 & $0.273 \pm 0.001$ & 751 & 0.300 & $0.324 \pm 0.006$ \\
\hline $\mathrm{MA}-\mathrm{A} / \mu \mathrm{m}^{2}$ & 768 & 3271 & $3951 \pm 117$ & 766 & 2860 & $3494 \pm 94$ \\
\hline MA-\#/MA sq. $\mathrm{mm}^{-1}$ & 768 & 7.65 & $8.18 \pm 0.19$ & 766 & 8.82 & $9.58 \pm 0.22$ \\
\hline MA- $\%(\%)$ & 768 & 2.54 & $3.13 \pm 0.10$ & 766 & 2.80 & $3.26 \pm 0.10$ \\
\hline Health assessment index & 794 & 30 & $33+1$ & 783 & 30 & $32+1$ \\
\hline
\end{tabular}

${ }^{a}$ Hepatic EROD activity was $<$ LOD in female bass $\left(n=1 ; 0.06\right.$ pmol min $\left.{ }^{-1} \mathrm{mg}^{-1}\right)$, male bass $\left(n=1 ; 0.35 \mathrm{pmol} \mathrm{min}^{-1} \mathrm{mg}^{-1}\right)$, female carp $(n=74 ; 0.01-$ $\left.0.78 \mathrm{pmol} \mathrm{min} \mathrm{mg}^{-1}\right)$, and male carp $\left(n=57 ; 0.03-3.76 \mathrm{pmol} \mathrm{min}^{-1} \mathrm{mg}^{-1}\right)$.
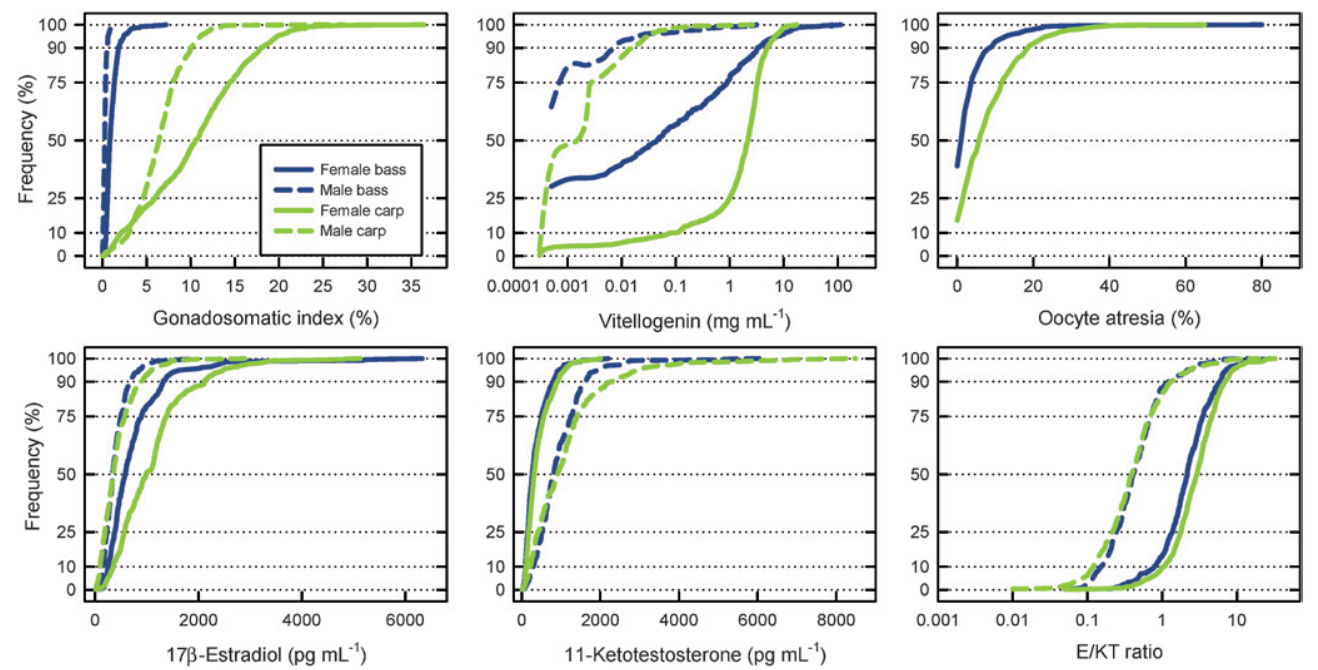

Fig. 4 Cumulative frequency distributions of reproductive biomarkers in bass and carp. 17ß-Estradiol and 11-ketotestosterone were not measured in samples from the Rio Grande or Columbia River basins.

explained only $8 \%$ of the total EROD variation in females and $9 \%$ in males (data not shown).

Statistically significant regression models of reproductive biomarkers as functions of contaminant concentrations explained $14-59 \%$ of the total variation in bass and $24-78 \%$ in carp (Table 5). There was little consistency among significant variables in the vitellogenin and gonadosomatic index models; however, vitellogenin concentrations in most bass were < LOD. Cyclodiene and other organochlorine pesticides, total PCBs, and elemental contaminants were significant in the models of
$17 \beta$-estradiol in bass and carp. Comparatively few chemicals were significant in the models of either 11-ketotestosterone or $\mathrm{E} / \mathrm{KT}$ ratio, and the models for E/KT ratios in female carp were not statistically significant. Cyclodiene pesticide residues and DDT isomers were positive in all the models of oocyte atresia.

\section{Principal components analysis}

Organochlorine and elemental chemicals. The number of statistically significant PCs and the total variation explained were 


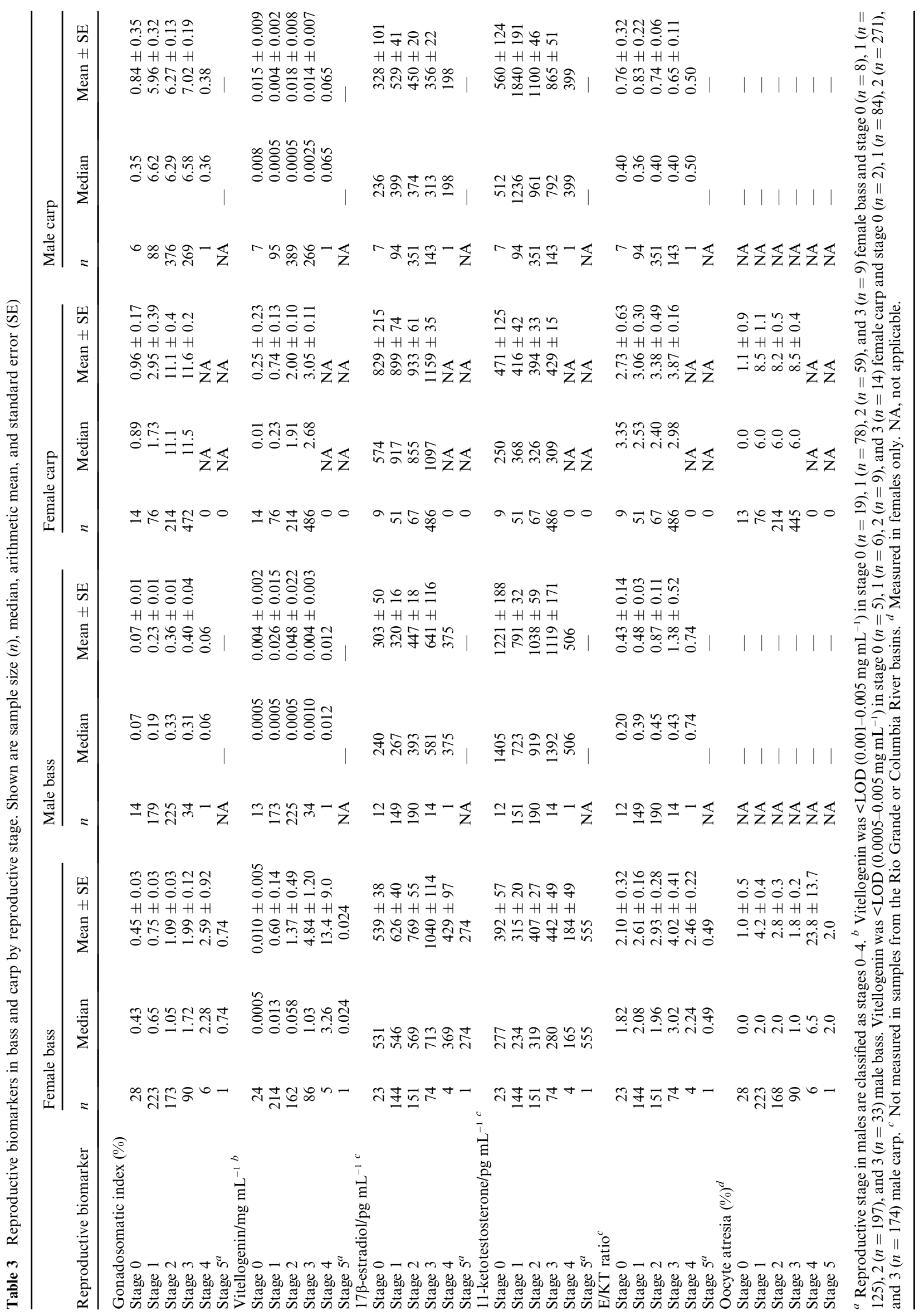


Table 4 Regression models for somatic indices, health assessment index, macrophage aggregate (MA) parameters, and hepatic ethoxyresorufin $O$-deethylase (EROD) activity as functions of contaminant concentrations in bass and carp. Shown are statistically significant $(p<0.05)$ positive and negative independent variables, degrees of freedom $(\mathrm{df})$, and coefficients of determination percent $\left[r^{2}(\%)\right]^{a}$

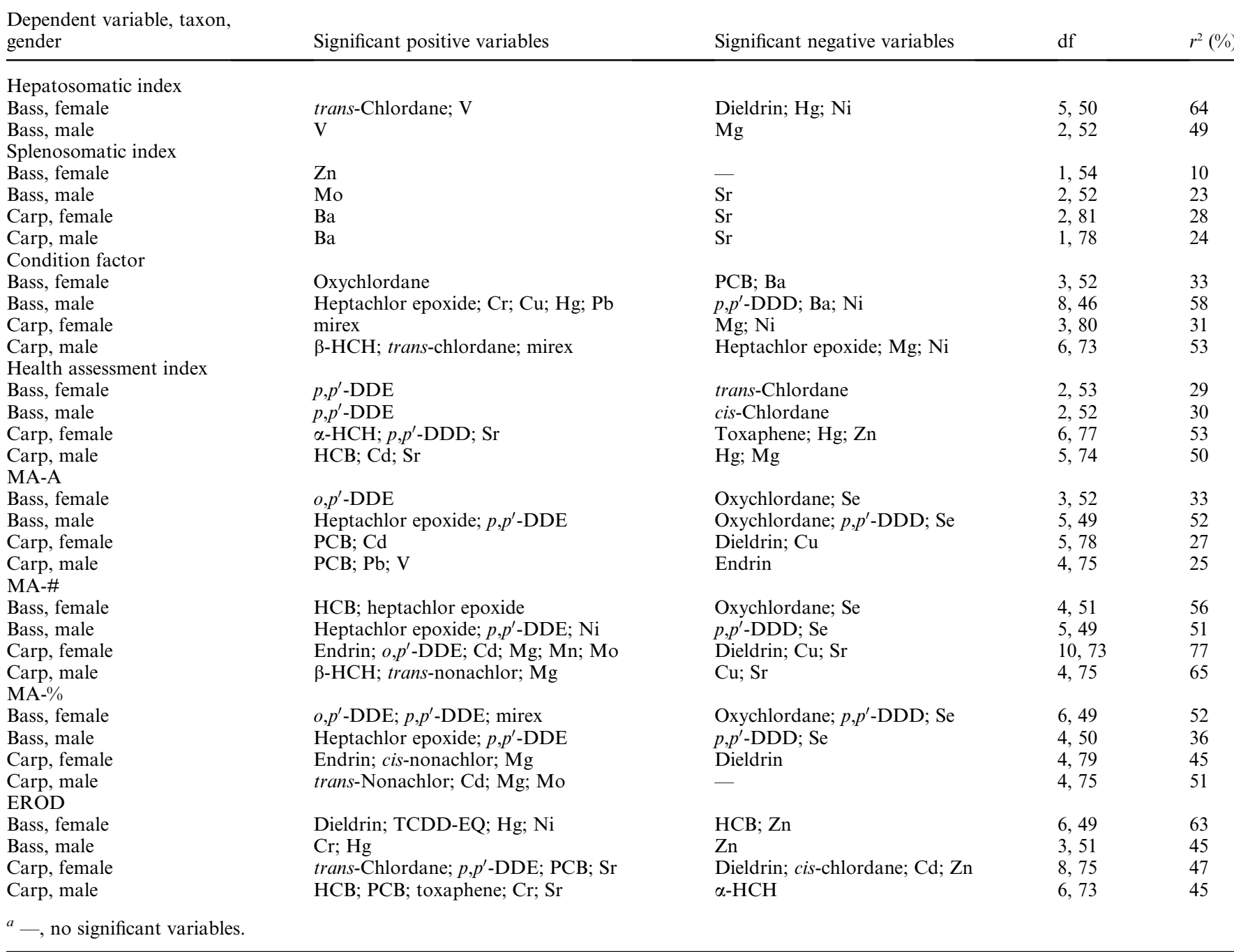

consistent among models, with eight to ten significant PCs explaining $75-79 \%$ of the total variation. PC1 and PC2 explained $33-36 \%$ in all models.

Patterns of chemical contaminant concentrations differed between taxa (Fig. 5A). Loading plots of PC1 and PC2 for allfish indicate that the differences were based on elemental contaminants that loaded negatively on PC1 and PC2 (e.g. $\mathrm{Hg}$ and $\mathrm{Mg}$; Fig. 5B). Separate PC analyses were therefore conducted for each taxon. Organochlorine chemical concentrations were not major determinants of the differences between taxa; the presence and amounts of organochlorine chemical residues, including agricultural pesticides, contributed more to the spatial differences evident in the contaminant patterns than to differences between taxa (Fig. 5B). Chlordane components, dieldrin, total PCBs, and TCDD-EQs were important in differentiating bass and carp from several sites in the MRB from other sites (Fig. 5A).

The spatial patterns for bass and carp differed, but the patterns within each taxon were similar in male, female, and combined- gender (i.e., all-bass, all-carp) PC models. All models are discussed, but only the all-bass and all-carp figures are presented. The scores plots from the bass models were characterized by distinct spatial groups that were well separated by basins on PC1 and PC2 (Fig. 5C). In the all-bass model, one group comprised sites in the MRB, RGB, CRB, and CORB, with a second group comprising sites in the ARB, MORB, SRB, and PRB (Fig. 5C). The patterns for female and male bass were associated with negative loadings on $\mathrm{PCl}$ for $\mathrm{Ba}, \mathrm{Mg}, \mathrm{Hg}$, and $\mathrm{Sr}$ (Fig. 5D). The groups were separated on PC2 by positive loadings for cyclodiene pesticides and total PCBs and negative loadings for $\mathrm{Cu}$, Mo, and V (Fig. 5D). Two sites (site 325 in the CORB and site 24 in the MRB) were separated from other sites on PC3 because of positive loadings for DDT isomers and toxaphene, which are not shown in Fig. 5.

Basin groupings were less evident for carp than bass. A group comprising sites in the CORB, ARB, MORB, SRB, and PRB were associated with negative loadings of $\mathrm{Sr}$ and $\mathrm{Se}$ on $\mathrm{PC} 1$ in all three carp models (Fig. 5E-F). All CORB sites plotted higher on 
Table 5 Reduced-rank ${ }^{a}$ regression models for biomarkers as functions of contaminant concentrations in bass and carp. Shown are statistically significant $(p<0.05)$ positive and negative independent variables, degrees of freedom $(\mathrm{df})$, and coefficients of determination percent $\left[r^{2}(\%)\right]$

\begin{tabular}{|c|c|c|c|c|}
\hline $\begin{array}{l}\text { Dependent variable, taxon, } \\
\text { gender }\end{array}$ & Significant positive variables & Significant negative variables & df & $r^{2}(\%)$ \\
\hline \multicolumn{5}{|l|}{ Vitellogenin } \\
\hline Carp, female & $\mathrm{Zn}$ & $\beta$-HCH; toxaphene; $\mathrm{As} ; \mathrm{Cu} ; \mathrm{Sr}$ & 6,59 & 41 \\
\hline Carp, male & cis-Chlordane; Mo & $\alpha-\mathrm{HCH} ; \beta-\mathrm{HCH}$; heptachlor epoxide & 5,47 & 78 \\
\hline \multicolumn{5}{|l|}{$17 \beta$-Estradiol } \\
\hline Carp, female & Dieldrin; oxychlordane; $\mathrm{Ba} ; \mathrm{Hg} ; \mathrm{Se} ; \mathrm{Zn}$ & trans-Chlordane; $\mathrm{Mg}$ & 8,57 & 55 \\
\hline Carp, male & $\mathrm{HCB}$; mirex; PCB; Hg; Mo; Sr & $p, p^{\prime}$-DDD & 8,44 & 70 \\
\hline \multicolumn{5}{|l|}{ 11-Ketotestosterone } \\
\hline Bass, female & Heptachlor epoxide; TCDD-EQ & trans-Chlordane; toxaphene; $\mathrm{Ba}$ & 5,27 & 59 \\
\hline Bass, male & $\mathrm{Se}$ & - & 1,38 & 14 \\
\hline Carp, female & $\mathrm{Ba} ; \mathrm{Zn}$ & $\mathrm{Mg}$ & 3,62 & 24 \\
\hline Carp, male & cis-Nonachlor; PCB; Mn & $p, p^{\prime}$-DDE & 4,48 & 35 \\
\hline Carp, male & Endrin; mirex & - & 2,50 & 25 \\
\hline \multicolumn{5}{|l|}{ Gonadosomatic index } \\
\hline Bass, female & Heptachlor epoxide & $p, p^{\prime}-\mathrm{DDE}$ & 2,30 & 43 \\
\hline Bass, male & HCB & $o, p^{\prime}-\mathrm{DDE}$ & 2,37 & 38 \\
\hline Carp, female & $\begin{array}{l}\text { Heptachlor epoxide; } p, p^{\prime} \text {-DDE; } \\
\text { PCB; As; Ba; Mo; Se }\end{array}$ & trans-Nonachlor; TCDD-EQ; Cr; Sr; V & 12,53 & 55 \\
\hline Carp, male & $\mathrm{Hg} ; \mathrm{Mo}$ & Toxaphene; Cd & 4,48 & 35 \\
\hline \multicolumn{5}{|l|}{ Oocyte atresia } \\
\hline Bass, female & Oxychlordane & $o, p^{\prime}$-DDE; Mo & 3,29 & 44 \\
\hline Carp, female & Dieldrin; cis-nonachlor; $p, p^{\prime}$-DDE; Hg & $\mathrm{HCB}$; heptachlor epoxide; $o, p^{\prime}$-DDD; $\mathrm{Pb}$ & 8,57 & 53 \\
\hline
\end{tabular}

PC3 because of a positive loading for Se. Sites 68, 76, and 206 were separated from other sites in the MRB by chlordane components, dieldrin, and total PCBs, which loaded positively on PC1 and negatively on PC2 (Fig. 5E-F). As was true for bass, several sites in the CORB and MRB also were separated by positive loadings on PC3 for DDT isomers, toxaphene, and Se.

Biomarkers. Overall, PCA models for biomarkers in bass and carp were similar, as significant loading factors were not consistent in either taxon. Nevertheless, more variation was explained by fewer PCs in the models for biomarkers than for contaminant concentrations. Four or five significant PCs explained $72-82 \%$ of the total variation in all models; PC1 and PC2 explained $45-50 \%$.

Most sites grouped together in the scores plot for female bass, with outlier sites evident because of variables that loaded high on PC1 and low on PC2 (Fig. 6A-B). Sites were separated along $\mathrm{PC} 1$ because of positive loadings for vitellogenin and gonadosomatic index and negative loadings for EROD activity (Fig. 6B). Basin groups were more evident for biomarkers in male bass than in females, but only on PC2. In general, male bass from sites in the MRB and CRB plotted higher on PC2 than sites from the other basins because of somatic indices (Fig. 6C-D). MA parameters loaded negatively on PC3 in the female and male bass models.

Spatial differences were evident in the scores plot for female carp (Fig. 6E). Sites in the MRB, RGB, and CRB plotted lower on PC2 than those from the other basins. Sites from several basins with PC2 scores $>$ were associated with positive loadings for age, hepatic EROD activity, and oocyte atresia (Fig. 6E-F). As was true in bass, MA parameters loaded negatively on PC3 in the female carp model. Site 336 (in the PRB) did not group with any other site because of positive loadings for length, weight, and gonadosomatic index on PC1 and PC3 (Fig. 6E-F). Most MRB sites grouped together in the scores plot for male carp, but patterns among sites in other basins were less evident (Fig. 6G); the group comprising MRB sites were differentiated from other sites on PC2 because of negative loadings for MA-A and MA-\# (Fig. 6G-H). Site 324 (in the CORB) was separated by positive loading for vitellogenin on PC3.

Contaminant concentrations and biomarkers. The number of statistically significant PCs and the total variation explained were consistent across all the combined chemical and biological models. Eleven or twelve significant PCs explained $77-81 \%$ of the total variation in all models; PC1 and PC2 explained 27-33\%. Contaminant concentrations were the main drivers of these combined models, and the plots generally resembled the chemical PCA models.

Patterns were similar in the combined PCA models for female and male bass. The scores plots were characterized by distinct spatial groups that were well separated by basins on PC1 and PC2. In the female and male bass models, MRB, RGB, and CRB sites were in one group; CORB sites were in another; and ARB, MORB, SRB, and PRB sites were in a third (Fig. 7A \& C). The basin separations in all the models were associated with negative loadings on $\mathrm{PC} 1$ for mirex, $\mathrm{Ba}, \mathrm{Hg}, \mathrm{Mg}, \mathrm{Sr}$, and hepatic EROD activity (Fig. 7B \& D). The groups were separated on PC2 by 

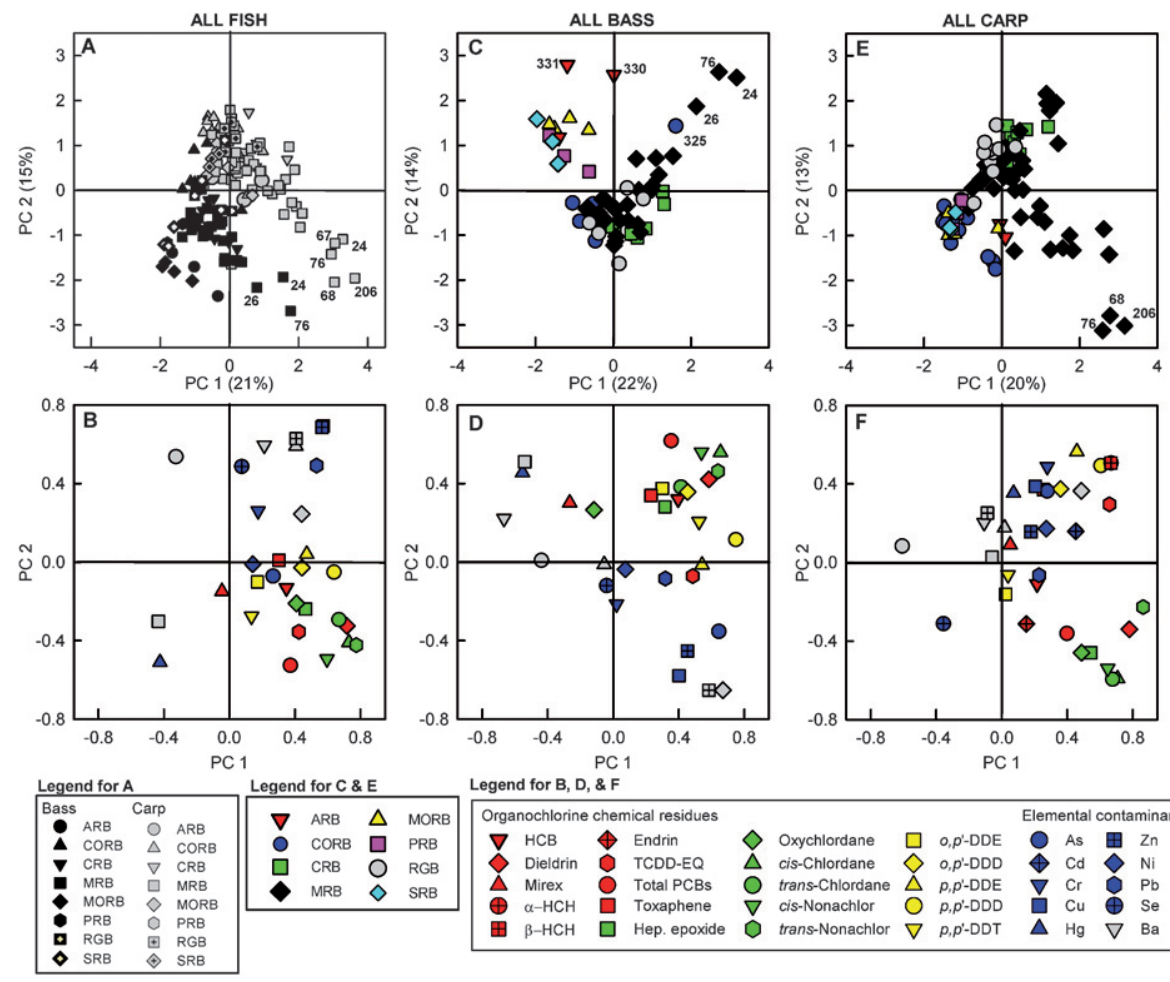

Legend for $\mathrm{B}, \mathrm{D}, \mathrm{\&}$ F

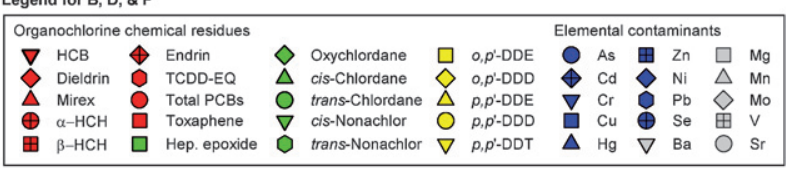

Fig. 5 Scatter plots of chemical contaminant concentrations in all fish (A), all bass (C), and all carp (E) on the axes representing principal components (PCs) 1 and 2 by basin. Percent variance explained by each PC is given in parentheses. Sites that did not follow the general trends were labeled. Scatter plots (B, D, and F) of factor loadings on PC1 and PC2 from the same model. Apalachicola River basin, ARB; Colorado River basin, CORB; Columbia River basin, CRB; Mississippi River basin, MRB; Mobile River basin, MORB; Pee Dee River basin, PRB; Rio Grande basin, RGB; Savannah River basin, SRB.

positive loadings for cyclodiene pesticides and total PCBs and negative loadings for elemental contaminants in the female and male bass models (Fig. 7B \& D). In female bass, site 325 (in the $\mathrm{CORB}$ ) and site 76 (in the MRB) were differentiated from other sites on PC3 because of positive loadings for DDT isomers, chlordane components, dieldrin, toxaphene, and $\mathrm{Pb}$. Sites 26 and 76 (in the MRB) were separated on PC2 in male bass because of positive loadings for chlordane components, dieldrin, and total PCBs (Fig. 7C-D). Sites in the MORB were also differentiated on $\mathrm{PC} 3$ in male bass because of positive loadings for $\mathrm{Hg}$, MA parameters, length, and weight.

Differences between genders were not evident in the combined chemical and biological models for carp. The scores plots from both carp models were characterized by two distinct spatial groups that were well separated by basins on PC1 and PC2. In the female and male carp models, MRB, RGB, and CRB sites were in one group and CORB, ARB, MORB, SRB, and PRB sites were in another (Fig. 7E \& G). The basin separations were associated with negative loadings on $\mathrm{PC} 1$ for age, $\mathrm{Se}$, and $\mathrm{Sr}$ and positive loadings for $\alpha-\mathrm{HCH}$ and $\beta-\mathrm{HCH}$ (Fig. 7F \& H). Vitellogenin also loaded negatively on PC1 in male carp (Fig. $7 \mathrm{H}$ ). The groups were separated on PC2 by loadings for cyclodiene pesticides and total PCBs (Fig. 7F \& H). Sites 67, 68, 76, and 206 (in the MRB) were differentiated from other sites on PC1 and PC2 because of positive loadings for chlordane components and dieldrin in females (Fig. 7E-F). Sites 76 and 206, along with sites 324 and 325 (in the CORB), also were differentiated in males because of negative loadings for chlordane components, dieldrin, and endrin on PC2 (Fig. 7G-H). The CORB sites were separated from other sites on PC3 because of positive loadings for $\mathrm{Mg}$ and Se in female carp.

\section{Discussion}

The bass and carp included in this study represented a large geographic range. Sites $(n=96)$ in eight basins represented a range of contaminant sources (e.g., mining, agriculture, industry, and urban areas) and key points in major rivers such as dams and tributary confluences. Many sites were co-located at National Contaminant Biomonitoring Program (NCBP) sites, which were typically located at key points in major drainages. ${ }^{27}$ Consequently, sites were hydrologically rather than statistically or connectivity representative. As such, the frequency distributions and other statistics presented here are not necessarily representative of the rivers and basins, only the fish populations of sampled sites. Nevertheless, because most of the sites were not selected to reflect specific contaminant sources, we assume that the sites accurately represent conditions in the eight river basins sampled. Chemical exposures at certain sites along these rivers may be more extreme than those observed here. In fact, known 'hot spots' of chemical contamination were generally avoided. The environments surrounding many of those contaminated areas would likely be targeted for sampling under the Clean Water Act. Moreover, the dynamic nature of river hydraulics 

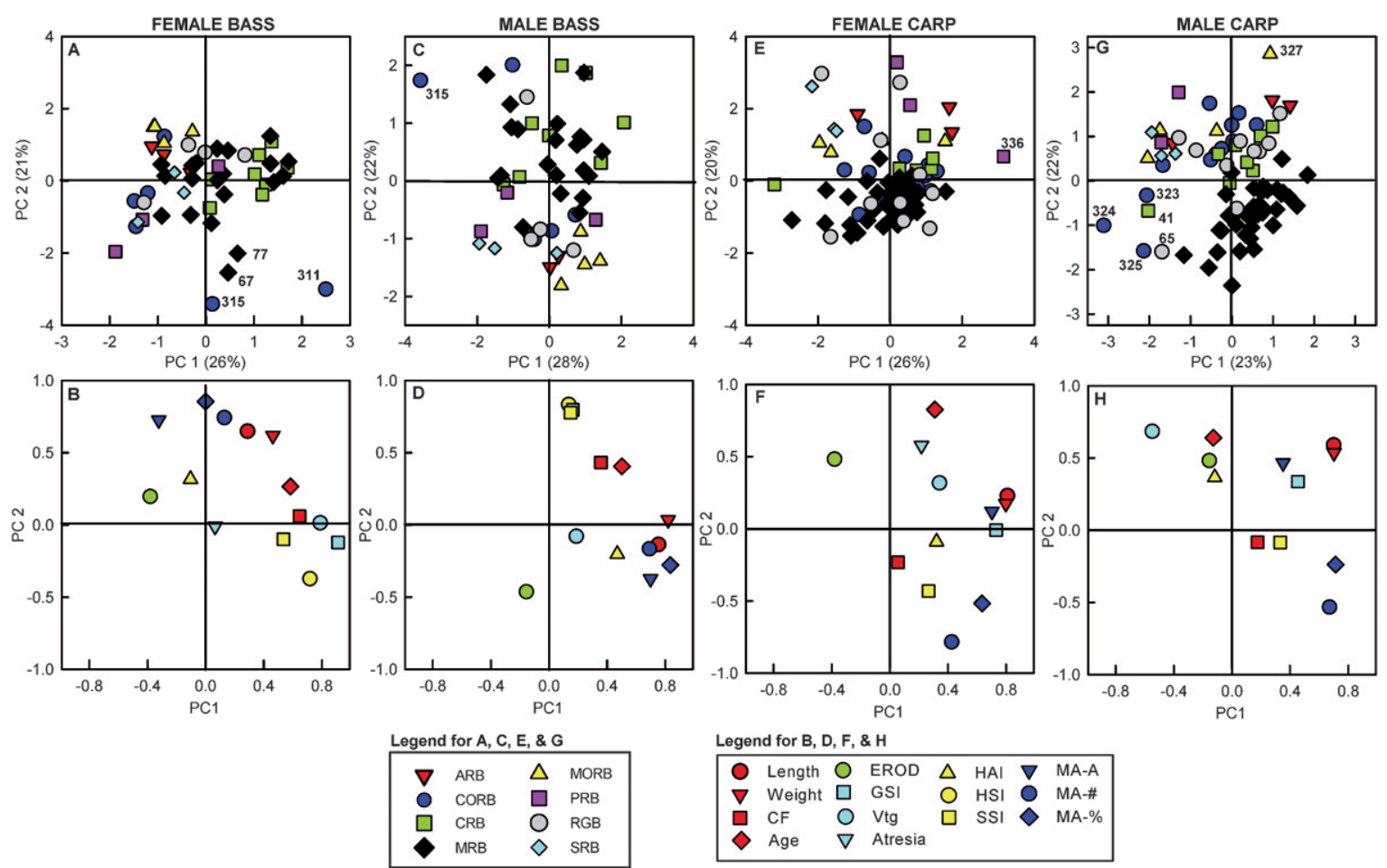

Fig. 6 Scatter plots of biomarkers in female bass (A), male bass (C), female carp (E), and male carp (G) on the axes representing principal components (PCs) 1 and 2 by basin. Percent variance explained by each PC is given in parentheses. Sites that did not follow the general trends were labeled. Scatter plots (B, D, F, and H) of factor loadings on PC1 and PC2 from the same model. Apalachicola River basin, ARB; Colorado River basin, CORB; Columbia River basin, CRB; Mississippi River basin, MRB; Mobile River basin, MORB; Pee Dee River basin, PRB; Rio Grande basin, RGB; Savannah River basin, SRB; CF, condition factor; GSI, gonadosomatic index; Vtg, vitellogenin; HAI, health assessment index; HSI, hepatosomatic index; SSI, splenosomatic index.

and the life history of the bass and carp ensure that the chemical exposures of the fish represent broad areas within the rivers.

The contaminant data presented here were summarized for individual basins in previous reports, ${ }^{15-19}$ but concentrations in bass and carp have not been compared among basins. The main chemical contaminants of concern in these studies included cyclodiene pesticides, DDT isomers, TCDD-EQ, Hg, and Se. Briefly, cyclodiene pesticides, which were used to combat soildwelling insects such as corn root worm and termites, co-occur, and concentrations were greatest in carp from the MRB. Concentrations of cyclodiene pesticides were also elevated near a manufacturing facility located in the MRB (site 76) but were generally low in the other basins. Total DDT concentrations were greatest in bass and carp from areas with intensive agriculture including the Lower Mississippi Rivers of the MRB, the Gila River in the CORB, and the mid-CRB. Toxaphene was used heavily on cotton after the ban of DDT; accordingly, concentrations were greatest in carp from the Lower MRB and the Gila River. Total PCB concentrations were greatest in fish at sites located near industrial or urban areas in the MRB (sites 23, 24, 67, 76, and 111), MORB (site 327), CORB (sites 320 and 324), and ARB (site 330). Dioxin-like activity was greatest in bass and carp throughout the MRB, the Snake River in the CRB, and the Coosa River in the MORB. Mercury concentrations were consistently greater in bass from the MORB, ARB, SRB, and PRB but were also elevated in the Mississippi River near Memphis (site 76), the Salmon River in the CRB, and below Amistad
Reservoir in the RGB. Elevated Se concentrations in bass and carp throughout the CORB, the Middle Rio Grande, and Arkansas-Red and Big Horn Rivers in the MRB were associated with the natural weathering of seleniferous shales, irrigation practices, and fossil fuel combustion. These geographic trends were for bass and carp only; contaminant concentration trends in other species may have differed.

\section{Contaminant concentrations}

The significant differences in concentrations of pentachloroanisole, cis-chlordane, trans-chlordane, $p, p^{\prime}$-DDT, endosulfan sulfate, $\mathrm{Ba}, \mathrm{Cd}, \mathrm{Cu}, \mathrm{Hg}, \mathrm{Mg}, \mathrm{Mn}, \mathrm{Pb}, \mathrm{Se}, \mathrm{V}$, and $\mathrm{Zn}$ between taxa highlight the importance of species selection in monitoring and contaminant studies. Adult bass and carp occupy different trophic levels, which affects their exposure to and accumulation of certain chemical contaminants. As a predatory species, bass would be expected to have higher concentrations of contaminants that bioaccumulate such as $\mathrm{Hg}$ and PCBs; indeed, concentrations of $\mathrm{Hg}$ were greater in bass than carp from the same location. However, the mean PCB concentration was not different between these two species. Common carp can bioaccumulate hydrophobic PCBs through sediment ingestion. ${ }^{28}$ The benthivorous forging behavior of carp puts this species in direct contact with metals and hydrophobic organic contaminants in sediments and invertebrates that they consume. In addition, the lower trophic status of carp may well have been 

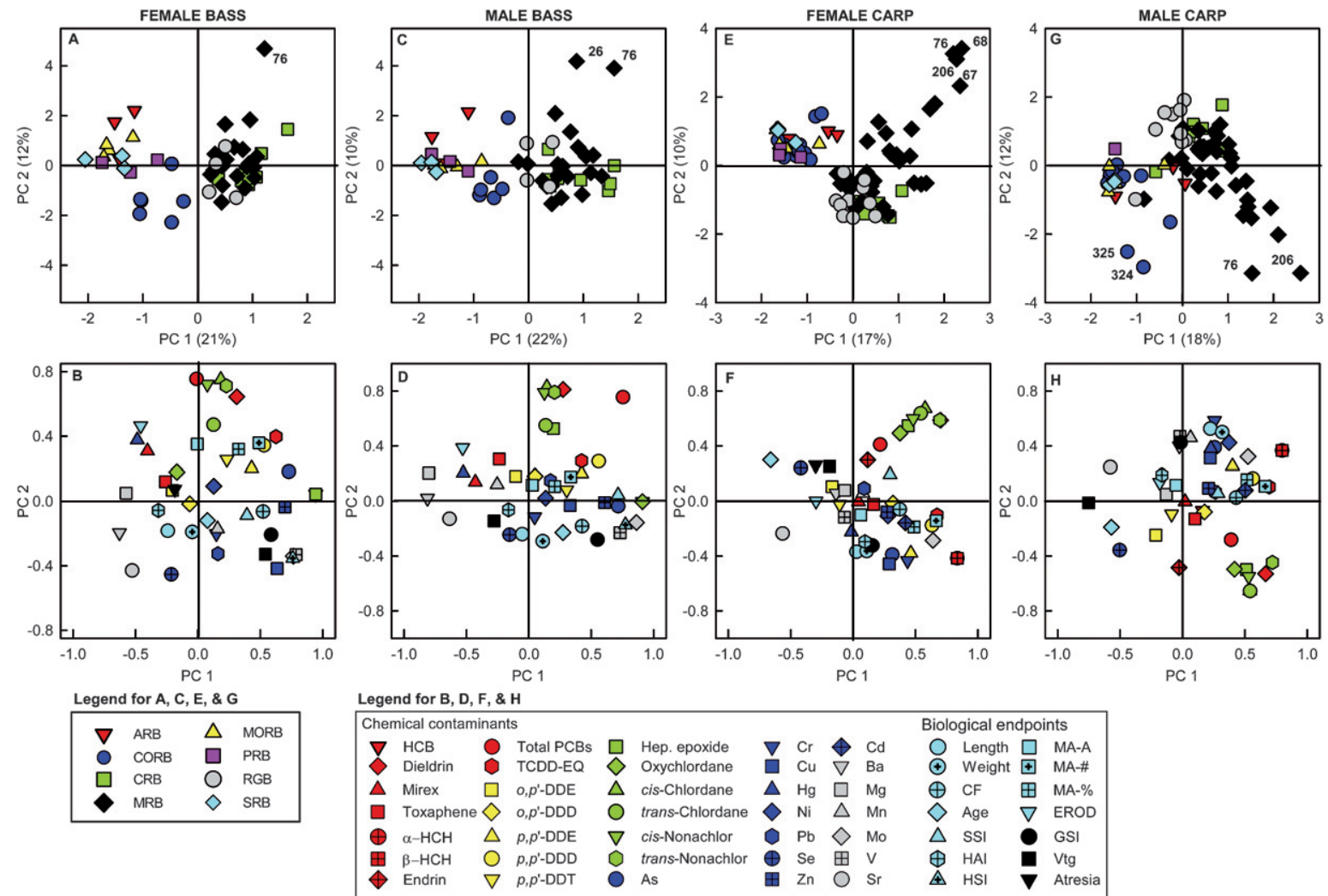

Fig. 7 Scatter plots of chemical contaminant concentrations and biomarkers in female bass (A), male bass (C), female carp (E), and male carp (G) on the axes representing principal components (PCs) 1 and 2 by basin. Percent variance explained by each PC is given in parentheses. Sites that did not follow the general trends were labeled. Scatter plots (B, D, F, and H) of factor loadings on PC1 and PC2 from the same model. Apalachicola River basin, ARB; Colorado River basin, CORB; Columbia River basin, CRB; Mississippi River basin, MRB; Mobile River basin, MORB; Pee Dee River basin, PRB; Rio Grande basin, RGB; Savannah River basin, SRB; CF, condition factor; GSI, gonadosomatic index; Vtg, vitellogenin; HAI, health assessment index; HSI, hepatosomatic index; SSI, splenosomatic index.

countered by their greater lipid content, with the net result being similar PCB concentrations in bass and carp. If lipid content differences were responsible for differing organochlorine concentrations between taxa, we would have expected to see differences for DDT isomers, which are among the most lipophilic contaminants we measured. The differences in the frequency distributions of DDT concentrations between bass and carp were minimal, indicating that the differing lipid content of these taxa was not the most important or only factor responsible for the differing $\mathrm{PCB}$ and DDT concentrations in bass and carp. In contrast, concentrations of chemicals that are more susceptible to metabolism, such as pentachloroanisole, endosulfan sulfate, and dacthal, were greater in carp than bass. These differences were likely due to lower rates of oxidation, conjugation, or excretion in carp. ${ }^{29,30}$ Our EROD data also indicated several fold lower hepatic cytochrome (CYP1A) activity in carp compared to bass, another indicator of lower metabolic activity in carp.

Pentachloroanisole results from the methylation of pentachlorophenol, which fish accumulate through their skin and gills. Thus, if carp have slower rates of methylation, they would be expected to have lower concentrations of pentachloroanisole. However, carp may have even lower rates of conjugation reactions or excretion, which might partly account for the elevated concentrations of pentachloroanisole relative to bass. Pentachloroanisole can rapidly concentrate in fatty tissues of freshwater fish. ${ }^{31}$ Technical-grade endosulfan, which contains two pure isomers (endosulfan I and II), is toxic to fish and accumulates in the liver of carp. ${ }^{32}$ Endosulfan sulfate can be detected in organisms due to the oxidation of endosulfan I and II; high concentrations of endosulfan II compared to endosulfan I in fish indicate recent endosulfan exposure. ${ }^{32}$ Tripathi and Verma ${ }^{30}$ concluded that endosulfan exposure can affect energy metabolism in fish by inhibiting transcription. Endosulfan also accumulates in fatty tissues of freshwater fish, and it may have been present in the gut contents of carp. Lower rates of conjugation reactions and excretion in $\operatorname{carp}^{30}$ may have also contributed to the greater concentrations of endosulfan relative to bass. In contrast to pentachloroanisole and endosulfan sulfate, little metabolism or degradation of dacthal occurs in fish tissue. ${ }^{33}$ Greater concentrations of dacthal in carp compared to bass may also represent the contribution of sediments ingested by carp and included in the whole-body fish samples.

The greatest toxaphene concentrations were in carp from sites 201-204 and 80, where few or no bass were collected. Therefore, concentration differences between taxa in the higher percentiles of the frequency distribution for toxaphene may be an artifact of the samples available for collection. Similar sampling artifacts 
were evident in the upper percentiles for heptachlor epoxide, oxychlordane, dacthal, $p, p^{\prime}$-DDD, and endosulfan I concentrations in carp.

Greater concentrations of $\mathrm{Ba}, \mathrm{Cd}, \mathrm{Cu}, \mathrm{Mn}, \mathrm{Pb}, \mathrm{Se}, \mathrm{V}$, and $\mathrm{Zn}$ in carp than bass may reflect differences in diet, foraging behavior, metabolic processes, and anatomy. Bass feed primarily on fish, whereas carp forage for aquatic insects and plants in sediments. The higher trophic status of bass compared to carp typically results in bass having greater concentrations of bioaccumulative contaminants. As noted for the organochlorine chemicals, the whole-body fish samples included gut contents. Incidental ingestion of sediment and detritus with food can be a substantial source of elemental contaminants. ${ }^{34}$ For example, sediments contributed $76 \%$ of the weight and $42 \%$ of the volume in the gut contents of the benthivorous blue sucker (Cycleptus elongaus). ${ }^{35}$ Therefore, the sediments and invertebrates commonly ingested by carp and included in the chemical analyses may have contributed to the greater concentrations of elemental contaminants. Conversely, $\mathrm{Mg}$ concentrations were greater in bass than carp, which influenced the PCA results. Relatively few published studies have reported concentrations of $\mathrm{Mg}$ in whole freshwater fish. Mean $\mathrm{Mg}$ concentrations were 147 $260 \mathrm{ug} \mathrm{g}^{-1}$ in whole-body juvenile carp. ${ }^{36}$ Mean $\mathrm{Mg}$ concentrations in largemouth bass and other centrarchids from Lake Eufaula, Alabama, were typically 400-500 ug $\mathrm{g}^{-1}$ whereas concentrations in other taxa were generally lower (343-390 ug $\left.\mathrm{g}^{-1}\right) .{ }^{37}$ Although no carp were analysed by Lawrence, ${ }^{37}$ the general trend of greater $\mathrm{Mg}$ concentrations in largemouth bass and other centrarchids than in other taxa is consistent with our findings, and the concentrations were nearly identical. Magnesium is an essential dietary nutrient; as such, it is not generally considered toxic to wildlife at concentrations found in fish. ${ }^{38}$

Total $\mathrm{Hg}$ concentrations were also greater in bass than carp. Methylmercury, which is the most toxic form of $\mathrm{Hg}$, represents greater than $90 \%$ of the $\mathrm{Hg}$ that occurs in fish, and it biomagnifies to high concentrations in aquatic food chains. ${ }^{39}$ Therefore, concentrations tend to be greater in predatory fish such as bass than in carp and other benthivores. Mercury was also one of the main drivers in the PCA models that separated bass from carp and also separated the MORB, ARB, SRB, and PRB from other basins in the bass models.

Differences between genders within taxa were only apparent for $\mathrm{Hg}$ and $\mathrm{Zn}$. Mercury concentrations in predatory fish typically increase with size, age, or both. ${ }^{39}$ Female bass were larger (weight and length) than males, which contributed to the greater $\mathrm{Hg}$ concentrations in females. Weight and length, but not gender, have been identified as important factors in $\mathrm{Hg}$ accumulation by bass. ${ }^{40,41}$ Cizdziel et $a l .{ }^{42}$ reported positive associations between fish-tissue (muscle, liver, and blood) $\mathrm{Hg}$ concentrations and length in bass. In contrast to $\mathrm{Hg}, \mathrm{Zn}$ concentrations were greater in carp than bass and greater in female than male carp. Concentrations $>100 \mu \mathrm{g} \mathrm{g}^{-1}$ occur regularly in carp, which partition $\mathrm{Zn}$ in the nuclei/cell debris fraction of digestive tract tissue and typically have greater concentrations than other fish species. ${ }^{43,44}$ The potential effects of high $\mathrm{Zn}$ concentrations in carp are unknown, but $\mathrm{Zn}$ is an essential element that is actively regulated in fish. Concentrations of $\mathrm{Zn}$ and other heavy metals can vary seasonally in carp; the lowest concentrations in muscle, gill, and liver typically occur during the spring. ${ }^{45}$ Most of the carp we analysed were collected during the late summer or fall, which is when the greatest $\mathrm{Zn}$ concentrations in liver occur. ${ }^{45}$ Although the greater $\mathrm{Zn}$ concentrations in carp may be due to increased absorption rates related to a physiological need of the fish, this relation is not associated with body size or age. ${ }^{46}$ The greater $\mathrm{Zn}$ concentrations in female carp may also be due to proportionately larger gonads in females; $\mathrm{Zn}$ concentrations can be up to six times greater in ovaries than testes. ${ }^{43}$

Previous studies have reported lower organochlorine chemical concentrations in female compared to male fish. ${ }^{47,48}$ Consequently, the lack of gender differences in our study was unexpected for organochlorine contaminants including total PCBs and TCDD-EQ. Lower organochlorine contaminant concentrations in female fish can occur through the loss of lipids and lipophilic contaminants during spawning, ${ }^{49}$ and gender differences can also be more pronounced with greater organochlorine concentrations. ${ }^{47}$ However, differing organochlorine concentrations in female and male fish also may depend on gender differences in diet, feeding and growth rates, and habitat use. Gender differences in bass and carp in our study might have been more apparent if more sites with greater organochlorine concentrations such as the Great Lakes and the northeastern United States had been sampled or if sampling had occurred prior to spawning. Overall, our results indicate that determining gender may not be an important consideration when comparing most organochlorine residue and elemental contaminant concentrations in bass and carp collected in the fall (post-spawn).

\section{Biomarkers}

Our analyses highlight the extent to which biomarkers can differ by taxon, gender, and reproductive stage and the need to account for these variables. Some biomarker differences were due to carp being larger and older than bass. For example, the greater number of splenic MAs in carp may be associated with the age differences. ${ }^{50}$ Taxa differences in hepatic EROD activities were evident. Bass consistently had greater hepatic EROD activities compared to carp, and female fish had slightly lower hepatic EROD activity than males of the same taxon. These findings are consistent with the EROD literature. ${ }^{22}$ Greater vitellogenin concentrations, 17 $\beta$-estradiol concentration, E/KT ratios, and oocyte atresia in female carp compared to female bass may be related to the sequential spawning of carp, which spawn multiple times over the growing season; bass spawn once in the spring or early summer.

\section{Regression analysis}

Few statistically significant variables were common to all the regression models. This may be partially due to the large percentage of censored values for some contaminants (i.e., hexachlorobenzene, $\alpha$-HCH, chlordane components, $o, p^{\prime}$-DDT isomers, mirex, and toxaphene). Although chemical contaminants for which $\leq 10$ samples exceeded the LOD were excluded from the analysis, most of those remaining were still represented by a high proportion of censored values. In fact, $p, p^{\prime}$-DDE, $p, p^{\prime}$ DDD, total PCBs, and TCDD-EQ were the only organochlorine residues that were $>$ LOD in most bass and carp samples. 
The fit of the regressions differed among the models, but few had coefficients of determination that exceeded 60\% (e.g., hepatosomatic index and EROD in female bass; MA-\# in female and male carp; $17 \beta$-estradiol in male carp). Dieldrin, $\mathrm{Hg}$, and $\mathrm{Ni}$, which were not correlated with each other, were associated with lower hepatosomatic index and increased hepatic EROD activity in female bass. Regressions of EROD activity were positively correlated with TCDD-EQ in female bass models and with total PCBs in the carp models. These results are consistent with known mechanisms of EROD regulation through the aryl hydrocarbon receptor. ${ }^{22}$ Hepatic EROD activity was also inversely correlated with concentrations of $\mathrm{Zn}$ in most models, but we are not aware of a mechanistic rationale or underpinning for these correlations.

The number of MAs increased with increasing endrin, $\mathrm{HCH}$, $\mathrm{Cd}$, and $\mathrm{Mg}$ concentrations and decreasing $\mathrm{Cu}$ and $\mathrm{Sr}$ concentrations in at least one carp model. Mercury was not significant in any of the MA models, which was contrary the findings of Schwindt et al., ${ }^{51}$ who reported increasing MA\% with $\mathrm{Hg}$ concentrations in salmonid fishes. Macrophage aggregates generally accumulate over time, ${ }^{50}$ as does $\mathrm{Hg}^{39}$ In our data set, the MA parameters were correlated with age in carp and bass from the $\mathrm{MRB},{ }^{15} \mathrm{RGB},{ }^{16}$ and $\mathrm{CRB},{ }^{17}$ and age-adjusted MA values were analysed and reported. However, the relations between the MA parameters and age were not consistently significant in the CORB,${ }^{18}$ the southeastern U.S. basins, ${ }^{19}$ or in the combined data set we analysed. Regression models for vitellogenin and $17 \beta$-estradiol in male carp had among the greatest coefficients of determination; most significant variables were organic chemical residues. Interpretation of these results were confounded by the large number of samples that had vitellogenin concentrations < LOD, but male carp with greater vitellogenin concentrations also had greater concentrations of cis-chlordane and Mo and lower concentrations of $\alpha-\mathrm{HCH}, \beta-\mathrm{HCH}$, and heptachlor epoxide. Greater $17 \beta$-estradiol concentrations in male carp were associated with increasing $\mathrm{HCB}$, mirex, total PCBs, $\mathrm{Hg}$, $\mathrm{Mo}$, and $\mathrm{Sr}$ concentrations and decreasing $p, p^{\prime}$-DDD concentrations.

The models describing relations between steroid hormones and contaminants were among the weakest, which is consistent with the strict internal regulation of hormone concentrations by teleosts. Steroid hormones are regulated through the hypothalamic-pituitary-gonadal axis and multiple feedback pathways. ${ }^{52}$ Therefore, dysregulation of these pathways by chemical contaminants might not be expected to occur along a gradient but rather in an all-or-nothing fashion. Overall, the contaminant concentrations were not good predictors of the biomarkers we measured, indicating that the biomarkers were not sufficiently sensitive to respond at the concentrations to which the fish were exposed. However and as mentioned previously, the power of the regression analysis was likely influenced by the high number of censored values for contaminant concentrations. In addition, the chemical contaminants we measured in the fish represent only a fraction of those to which they were potentially exposed.

\section{Principal components analysis}

Multivariate analyses such as PCA and discriminant analysis have been used to illustrate relations between fish health indicators and chemical contaminants that may not be evident from tabular summaries. ${ }^{53,54} \mathrm{We}$ used PCA to examine associations between the large number of measured variables and their interactions and how these endpoints relate to one another spatially. The PCA was also used to assess whether any chemical and biological endpoints were redundant, which could lead to potential cost savings for future studies. However, the chemical contaminants measured changed from 1995-2004, and analytical methods improved, which resulted in multiple LODs over the course of the studies. In addition, biomarkers, which were not measured in every fish from all sampling periods, were measured in individual fish whereas contaminant concentrations were measured in composite samples. These factors confound the relations of these chemical and biological endpoints. Simply excluding values <LOD from the dataset was not realistic because the statistical programs (PROC FACTOR and PROC REG) will only include observations with values for all variables $(n<20)$. To be consistent in our approach to the censoring issue, one-half the detection limit was used for the summary statistics, step-wise regression analysis, and PCA. Due to the limitations associated with this approach, our interpretation of the statistical results was extremely conservative.

Distinct basin groupings were evident in the score plots for the contaminant PCA models, but not for the biomarkers. The biomarkers are general indicators of fish health that were similar among basins and sites. Although our approach was consistent with previous studies that used PCA to examine relations among biomarkers, ${ }^{55,56,57}$ the biomarkers included in these earlier studies were biochemical endpoints with known, contaminant-specific responses. Hepatic EROD activity was the only biomarker we measured that has been directly linked to contaminant exposure. ${ }^{22}$ The results of the biomarker PCA models also indicate that the exposure gradient for most contaminants may not have been wide enough among our sites to elicit biomarker responses. In other words, the resolution of the biomarker models may have been better if more contaminated sites had been sampled. Nevertheless, the lack of concordance between the two sets of models indicate that they provide different (i.e., uncorrelated) information, which was the intent of the study design. The biomarkers were not selected to specifically reflect the measured chemicals but were intended to be diagnostic of the reproductive, endocrine, and immune health of fish and to integrate the overall response of organisms to environmental stressors including chemical contaminants employed as part of a weight-of-evidence approach. ${ }^{23}$ Consequently, contaminant concentrations were the main drivers in the combined contaminant and biomarker PCA models.

\section{Implications for long-term monitoring}

Fish sampling and the suite of chemical and biological methods used in this study represented one component of a tiered, multicomponent program initially designed to monitor contaminants and their effects in a broad array of habitats and species; the strategy focused on description of trends and not hypothesis testing. ${ }^{23,58}$ In the mid-1990s, it was perceived that most of the contaminants for which the analysis of animal carcasses represented a suitable monitoring strategy (i.e., organochlorine pesticides, PCBs, metals) had been regulated, and that 
environmental concentrations of these so-called 'legacy contaminants' were declining in the U.S. The notable exceptions were concentrations of $\mathrm{Hg}$, which were increasing in some locales due to atmospheric deposition; ${ }^{59,60}$ and $\mathrm{Se}$, which was also increasing in some agricultural areas due primarily to the effects of irrigation and elsewhere from the combustion of fossil fuels. ${ }^{27}$ The intent was to minimize the monitoring resources devoted to the legacy contaminants and to focus instead on broadening the approach to include more contemporary contaminants such as water-soluble pesticides and other chemicals that tend not to bioaccumulate. This was to be achieved by measuring biological responses (including biomarkers) and would ultimately be complimented by chemical analyses of other media such as water and sediment. ${ }^{61}$ The Tier-1 chemical and biological methods we used were essentially screening tools selected to document exposure of the fish to the widest variety of chemical contaminants at the lowest cost and with minimal redundancy. Chemical methods were therefore required only to be able to detect exposure of the fish to biologically relevant (i.e., toxic) concentrations of contaminants based on contemporaneous information rather than to precisely measure very low concentrations. Composite samples were analysed to further reduce analytical costs. Biological methods were similarly selected to reflect exposure to a wide variety of chemicals, with the knowledge that other factors might also be involved. In the tiered approach, positive Tier-1 chemical or biomarker findings would trigger follow-up (i.e., Tier 2) investigations using more sensitive (and more diagnostic) chemical and biological methods to determine the cause or causes of the Tier 1 findings.

Although adequate and efficient for monitoring, this multitiered strategy has created problems for long-term data analysis and interpretation. The most obvious of these is the large number of concentrations < LOD. While sufficient for Tier-1 screening assessments, the statistical analysis of such data is inherently problematic, as illustrated by our data. However, this is a study design and not a statistical method issue; the LOD issue would persist even if other multivariate statistical analyses such as factor analysis, discriminant analysis, canonical correlation analysis, and cluster analysis were used. ${ }^{62}$ The LOD of most organochlorine residues was $10 \mathrm{ng} \mathrm{g}^{-1}$ for $\mathrm{MRB}, \mathrm{RGB}$, and $\mathrm{CRB}$ samples and $<0.5 \mathrm{ng} \mathrm{g}^{-1}$ for $\mathrm{CORB}, \mathrm{MORB}, \mathrm{ARB}, \mathrm{SRB}$, and PRB samples. To account for these differences, we replaced any concentration less than the greatest LOD for a particular contaminant with the greatest LOD, which excluded some lowconcentration samples from the CORB, MORB, SRB, and PRB. One might argue that concentrations < LOD are below effect thresholds and are not of concern; however, biological effects thresholds are unknown for many of these contaminants as are cumulative effects. Therefore, some subtle relations between chemical and biomarkers may have been masked by the high LODs. Other monitoring programs that span decades are likely to incur similar issues as analytical methods improve. Monitoring programs need to ensure that LODs are low enough to achieve their goals, which typically include documenting temporal and geographic trends in certain media, evaluating the contaminant risk, or both. These goals may require different LODs and, consequently, costs. The percentile distributions from our data could be used as indicators of what LODs need to be to avoid this multiple censoring level issue. The LOD issue is especially problematic if the monitoring goals include detection of rising concentrations before they reach levels of concern. Levels of concern change frequently, usually becoming lower as new findings reveal previously unknown effects. Such is the situation for the $o, p^{\prime}$-DDT isomers, which were generally considered environmentally benign relative to the $p, p^{\prime}$-DDT isomers. Research has shown that these long-ignored compounds are estrogenic. ${ }^{63-65}$ Accordingly, the analytical methods used to generate our data evolved to reflect new knowledge, which in turn created the multiple LODs and other statistical problems that we encountered.

Measurement of contaminants in composite samples for comparison with biomarkers in individual fish limits the utility and precision of statistical models. Ideally, contaminant concentrations would be measured in individual fish for direct comparison with biomarkers in those same fish, but this approach would necessitate unrealistically high analytical costs. As noted by Bauch et al., ${ }^{61}$ the pairing of biomarker responses based on individual fish with analytical data from composite samples is inherently problematic, for several reasons. The amount of tissue contributed by each fish to composites was proportional to fish weight. Unless all the fish in the sample were of approximately the same weight, larger fish, in which contaminant concentrations may be higher, contribute proportionally more than smaller fish, which could introduce bias. In contrast, each fish was weighted equally when the mean biomarker responses for the fish in each composite was computed. In so doing, extremes for the biological variables, which may have been averaged across fish that differed in size, maturity, and reproductive stage, were also masked. For example, vitellogenin concentrations were $<$ LOD in nine of ten male carp from site 112 in the MRB, but was $2.645 \mathrm{mg} \mathrm{mL}^{-1}$ in one fish; the latter was within the range of previtellogenic females. Analysis of contaminant concentrations in each fish may have provided a better understanding of the relations between the biomarkers and contaminant concentrations. Masking of the extremes in this manner no doubt affected the results of the regression and $\mathrm{PC}$ analyses.

The chemical and biological methods we evaluated were specifically selected to avoid redundancy, and the monitoring strategy incorporated both general and specific biomarkers. A weight-of-evidence approach was employed to ensure that exposure to the greatest number of contaminants could be detected. Specific biomarkers, such as EROD activity, respond to individual contaminants or classes of contaminants, are generally quite sensitive, and respond rapidly following exposure. They can provide a warning of impending or incipient problems for particular contaminants and are typically indicators of exposure rather than effect. General biomarkers provide more broad information about contaminant-related stress, typically at a higher level of biological organization (tissue or organ system). General biomarkers, such as those indicative of organism, population, or community health, can be used to assess the cumulative effects of multiple contaminants and the combined effects of contaminants and other environmental stressors such as nutrition, sedimentation, eutrophication, and disease. Biomarkers diagnostic of reproductive health were included because of the growing interest in the effects of chemicals on the endocrine system. Fish health assessments and histopathological analysis were included in attempt to integrate the overall 
responses of organisms to environmental stressors, including exposure to xenobiotics. Most of the biomarkers selected were general biomarkers. Defining "normal" conditions or levels for these general biomarkers is difficult because they are influenced by environmental factors (temperature, season, etc) other than contaminant concentrations. Normal conditions for fish health indicators such as condition factor, hepatosomatic index, and splenosomatic index that may not be as greatly influenced by environmental factors are easier to define, and as such, may be more informative for monitoring.

Reproductive biomarkers in large scale monitoring studies are also difficult to interpret because they are influenced by species, gender, gonadal maturation, and environmental factors such as temperature that vary temporally and spatially. The effects of these variables on reproductive biomarker responses were minimized by collecting the fish after spawning and characterizing their gonadal maturity histologically. Our distribution data for gonadosomatic index, vitellogenin concentrations, $17 \beta$-estradiol concentrations, 11-ketotestosterone concentrations, E/KT ratios, and oocyte atresia represent some of the most comprehensive information available for bass and carp. Although reproductive biomarkers are used often in contaminant studies, conclusions from these data may be overstated because the studies fail to control or otherwise account for confounding factors including gonadal maturation, spawning time, and even gender. For example, several studies reached conclusions about differences in steroid hormones, gonadosomatic index, and vitellogenin in fish from various locations without accounting for reproductive stage. ${ }^{66,67,68,69}$ Our data indicate that even collecting fish within a short time period (several days to several weeks) does not ensure that they will be in the same stage of gonadal maturation. For example, male carp collected from three Gila River sites in southern Arizona within a 10-day period represented stages $0-4 .{ }^{19}$ Overall, the utility of reproductive biomarkers in large-scale monitoring studies may be limited considering these factors. Other general biomarkers, such as ponderal and meristic indices, can also be influenced by some of these same factors. However, they will probably continue to be used because they are easy to measure, can be computed from field data, and have no post-collection laboratory costs.

There are also limitations associated with multiple regression and PCA, both of which are correlation analyses. Studies such as ours, which span broad geographic areas, are exclusively exploratory, not explanatory. Correlations quantify associations between measured variables, regardless of the number of variables and statistical tools employed. Consequently, determining the causes of the biological findings was not an objective of this study. Rather, carefully planned and controlled field and laboratory research is required to document cause-effect relationships between chemical contaminants and biomarkers. The foundation of biomarker-based monitoring is the understanding of the factors that influence the biomarkers based on such research; that is, interpretation of biomarker findings is based more on knowledge of the biomarkers than on empirical relations. Such relations typically generate more questions than answers, but may suggest testable hypotheses that can be evaluated through subsequent laboratory research and more focused field studies.

\section{Conclusions}

Several recommendations for the design of future contaminant monitoring efforts can be made based on the evaluation of our data. First, although some organochlorine chemicals including HCHs, endrin, aldrin, heptachlor, endosulfans I and II, methoxychlor, and toxaphene were rarely detected (>LOD) in bass or carp at biologically relevant (i.e., toxic) concentrations based on contemporary toxicity information, continued monitoring may be warranted. Endosulfan and methoxychlor are still used in the U.S., and the other compounds may still be used elsewhere in the world. As noted for the $o, p^{\prime}$-DDT isomers, newly discovered effects may be associated with contaminant concentrations previously thought to be benign. In addition, government agencies are often required to assure the public that fish are safe for consumption by humans and wildlife, which requires periodic analyses for accumulative contaminants. Point sources of these contaminants also remain, which require continued monitoring. Second, gender had little influence on the concentrations of most analytes. Consequently, monitoring programs could reduce their costs by not analysing males and females separately for many contaminants. Third, taxon differences in contaminant concentrations, which were not exclusively related to differing lipid content in our data, are also important to consider due to trophic position influences on contaminant exposures, metabolic difference among taxa, and species-specific differences in regulation of metals. Finally, the study design should be carefully planned to avoid analytical limitations such as multiple censoring levels and comparisons of individual versus composite samples. Investigators should recognize that analytical methods will likely improve or change over the course of long term monitoring, which will confound the analysis of the data. The sampling design and field protocol should be sufficiently flexible to allow for analysis of new chemicals and biomarkers as methods and information needs evolve. Biomarkers should be chosen carefully for monitoring efforts; information provided by biomarkers in long term monitoring will be minimal if their limitations are not understood.

\section{Acknowledgements}

The BEST Program was managed by the Status and Trends Program of the U.S. Geological Survey. K. Chojnacki provided the map, and W. Bryant provided information on the statistical analyses. P. Anderson, V. Blazer, N. Denslow, T. Gross, T. May, and $\mathrm{C}$. Orazio were co-principal investigators of primary biomonitoring investigations from which this paper was derived. We also thank the BEST Project managers (W. Willford, C. Bunck, T. Bartish, and J. Coyle) and the numerous people who participated in the field and laboratory portions of the original investigations. P. Anderson, R. Breckenridge, and J. Buck reviewed earlier versions of this manuscript. Any use of trade, product, or firm names is for descriptive purposes only and does not imply endorsement by the U.S. Government.

\section{References}

1 E. Sorenson, Arch. Toxicol., 1988, 61, 324-329.

2 P. E. Drevnick and M. B. Sandheinrich, Environ. Sci. Technol., 2003, 37, 4390-4396. 
3 J. M. Blais, Can. J. Fish. Aquat. Sci., 2005, 62, 236-243.

4 R. J. Hugget, R. A. Kimerle, P. M. Merhle Jr. and H. L. Bergman, Biomarkers: Biochemical, Physiological, and Histological Markers of Anthropogenic Stress, Lewis Publishers, Boca Raton, FL, 1992.

5 R. van der Oost, J. Beyer and N. Vermeulen, Environ. Toxicol. Pharmacol., 2003, 13, 57-149.

6 D. E. Hinton, P. C. Baumann, G. C. Gardner, W. E. Hawkins, J. D. Hendricks, R. A. Murchelano and M. S. Okihiro, in Biomarkers: Biochemical, Physiological and Histological Markers of Anthropogenic Stress, ed. R. J. Huggett, R. A. Kimerle, P. M. Mehrle Jr. and H. L. Bergman, Lewis Publishers, Boca Raton, FL, 1992, pp. 155-210.

7 T. K. Collier, Hum. Ecol. Risk Assess., 2003, 9, 259-266.

8 J. W. Anderson, S. I. Hartwell and M. J. Hameedi, Environ. Sci. Technol., 2005, 39, 17-23.

9 J. W. Fournie, J. K. Summers, L. A. Courtney, V. D. Engle and V. S. Blazer, J. Aquat. Anim. Health, 2001, 13, 105-116.

10 L. L. Johnson, T. K. Collier and J. E. Stein, Aquat. Conserv.: Mar. Freshwater Ecosys., 2002, 12, 517-538.

11 M. S. Myers, L. L. Johnson and T. K. Collier, Hum. Ecol. Risk Assess., 2003, 9, 67-94.

12 K. K. Lehtonen, D. Schiedek, A. Kohler, T. Lang, P. J. Vuorinen, L. Forlin, J. Barsiene, J. Pempkowiak and J. Gercken, Mar. Pollut. Bull., 2006, 53, 523-537.

13 M. Eggens, A. Bergman, D. Vethaak, M. van der Weiden, M. Celander and J. P. Boon, Aquat. Toxicol., 1995, 32, 211-225.

14 A. Skouras, K. Broeg, H. Dizer, H. von Westernhagen, P. D. Hansen and D. Steinhagen, Helgol. Mar. Res., 2003, 57, 190-198.

15 C. J. Schmitt, Biomonitoring of Environmental Status and Trends (BEST) Program: Environmental contaminants and their effects on fish in the Mississippi River Basin, Biological Science Report USGS/ BRD/BSR 2002-0004, U.S. Geological Survey, Columbia, MO, 2002.

16 C. J. Schmitt, J. E. Hinck, V. S. Blazer, N. D. Denslow, G. M. Dethloff, T. M. Bartish, J. J. Coyle and D. E. Tillitt, Sci. Total Environ., 2005, 250, 161-193.

17 J. E. Hinck, C. J. Schmitt, V. S. Blazer, N. D. Denslow, T. M. Bartish, P. J. Anderson, J. J. Coyle, G. M. Dethloff and D. E. Tillitt, Sci. Total Environ., 2006, 366, 549-578.

18 J. E. Hinck, V. S. Blazer, N. D. Denslow, K. R. Echols, T. S. Gross, T. W. May, P. J. Anderson, J. J. Coyle and D. E. Tillitt, Sci. Total Environ., 2007, 378, 376-402.

19 J. E. Hinck, V. S. Blazer, N. D. Denslow, K. R. Echols, R. W. Gale, C. Wieser, T. W. May, M. R. Ellersieck, J. J. Coyle and D. E. Tillitt, Sci. Total Environ., 2008, 390, 538-557.

20 J. J. Whyte, C. J. Schmitt and D. E. Tillitt, Crit. Rev. Toxicol., 2004, 34, $1-83$.

21 G. T. Ankley, D. E. Tillitt, J. P. Giesy, P. D. Jones and D. A. Verbrugge, Can. J. Fish. Aquat. Sci., 1991, 48, 1685-1690.

22 J. J. Whyte, R. E. Jung, C. J. Schmitt and D. E. Tillitt, Crit. Rev. Toxicol., 2000, 30, 347-570.

23 C. J. Schmitt and G. M. Dethloff, Biomonitoring of Environmental Status and Trends (BEST) Program: selected methods for monitoring chemical contaminants and their effects in aquatic ecosystems, Information and Technology Report 2000-0005, U.S. Geological Survey, Columbia, MO, 2000.

24 A. Lorenzen and S. W. Kennedy, Anal. Biochem., 1993, 21, 346-348.

25 D. J. Saville, Am. Stat., 1990, 44, 174-180.

26 W. W. Cooley and P. R. Lohnes, Multivariate Data Analysis, John Wiley \& Sons, New York, 1971.

27 C. J. Schmitt, J. L. Zajicek, T. W. May and D. F. Cowman, Rev. Environ. Contam. Toxicol., 1999, 162, 43-104.

28 C. T. A. Moermond, F. C. Roozen, J. J. Zwolsman and A. A. Koelmans, Environ. Sci. Technol., 2004, 38, 4503-4509.

29 D. A. Trujillo, L. E. Ray, H. E. Murray and C. S. Giam, Chemosphere, 1982, 11, 25-31.

30 G. Tripathi and P. Verma, Biomed. Environ. Sci., 2004, 17, 47-56.

31 A. H. Glickman, C. N. Statham, A. Wu and J. J. Lech, Toxicol. Appl. Pharmacol., 1977, 41, 649-658.

32 B. Nowak, A. Goodsell and M. Julli, Ecotoxicology, 1995, 4, $363-$ 371 .

33 U.S. Environmental Protection Agency, Reregistration Eligibility Decision (RED) DCPA, Prevention, Pesticides, and Toxic Substances, Report EPA738-R-98-005, U.S. Environmental Protection Agency, Washington, DC, 1998.
34 J. M. Czarnezki, Bull. Environ. Contam. Toxicol., 1985, 34, 736745.

35 R. J. Rupprecht and L. A. Jahn, Trans. Am. Fish. Soc., 1980, 109, 323-326.

36 H. Dabrowska, K. H. Meyer-Burgdorff and K. D. Gunther, Fish. Physiol. Biochem., 1991, 9, 165-172.

37 J. M. Lawrence, Dynamics of chemical and physical characteristics of water, bottom muds, and aquatic life in a large impoundment on a river, Zoology-Entomology Department Series Fisheries No. 6, Auburn University, Alabama, 1968.

38 National Research Council, in Mineral Tolerance of Animals, Second Edition, ed. U.S. National Academy of Sciences Committee on Minerals and Toxic Substances in Diets and Water for Animals, 2005, pp. 224-234.

39 J. G. Wiener, D. P. Krabbenhoft, G. H. Heinz and A. M. Scheuhammer, in Handbook of Ecotoxicology,2nd Edition, ed. D. J. Hoffman, B. A. Rattner, G. A. Burton Jr. and J. N. Cairns Jr., CRC Press, Boca Raton, Florida, 2003, pp. 407-461.

40 T. R. Lange, H. E. Royals and L. L. Connor, Arch. Environ. Contam. Toxicol., 1994, 27, 466-471.

41 C. J. Schmitt and W. Brumbaugh, Arch. Environ. Contam. Toxicol., 2007, 53, 84-95.

42 J. Cizdziel, T. Hinners, C. Cross and J. Pollard, J. Environ. Monit., 2003, 5, 802-807.

43 L. Sun and S. Jeng, Zool. Stud., 1998, 37, 184-190.

44 L. T. Sun and S. S. Jeng, Fish. Physiol. Biochem., 1999, 20, 313-324.

45 S. Tekin-Özan and I. Kir, Environ. Monit. Assess., 2008, 138, 201-206.

46 S. S. Jeng and L. T. Sun, J. Nutr., 1981, 111, 134-140.

47 P. Larsson, L. Okla and L. Collvin, Environ. Toxicol. Chem., 1993, 12, 855-861.

48 C. P. Madenjian, G. E. Noguchi, R. C. Haas and K. S. Schrouder, Can. J. Fish. Aquat. Sci., 1998, 55, 1085-1092.

49 T. A. Johnston, A. T. Fisk, D. M. Whittle and D. C. Muir, Environ. Sci. Technol., 2002, 36, 4238-4244.

50 C. Agius and R. J. Roberts, J. Fish Dis., 2003, 26, 499-509.

51 A. R. Schwindt, J. W. Fournie, D. H. Landers, C. B. Schrek and M. L. Kent, Environ. Sci. Technol., 2008, 42, 1365-1370.

52 D. L. Villeneuve, P. Larkin, I. Knoebl, A. L. Miracle, M. D. Kahl, K. M. Jensen, E. A. Makynen, E. J. Durhan, B. J. Carter, N. D. Denslow and G. T. Ankley, Environ. Sci. Technol., 2007, 41, 321-330.

53 E. Casillas, D. Misitano, L. L. Johnson, L. D. Rhodes, T. K. Collier, J. E. Stein, B. B. McCain and U. Varanasi, Mar. Environ. Res., 1991, 31, 99-122.

54 S. M. Adams, K. D. Ham and J. J. Beauchamp, Environ. Toxicol. Chem., 1994, 13, 1673-1683.

55 R. van der Oost, E. Vindimian, P. J. van den Brink, K. Satumalay, H. Heida and N. P. E. Vermeulen, Aquat. Toxicol., 1997, 39, 45-75.

56 S. R. Schmolke, K. Broeg, S. Znader, V. Bissinger, P. D. Hansen, N. Kress, B. Herut, E. Jantzen, G. Kruner, A. Strum, W. Kiirting and H. von Westernhagen, Helgol. Mar. Res., 199, 53, pp. 257-266.

57 M. Machala, L. Dusek, K. Hilscherova, R. Kubinova, P. Jurajda, J. Neca, R. Ulrich, M. Gelnar, Z. Studnickova and I. Holoubek, Environ. Toxicol. Chem., 2001, 20, 1141-1148.

58 A. R. Olsen, B. P. Hayden, A. M. Ellison, G. W. Oehlert and S. R. Esterby, Bull. Ecol. Soc. Am., 1997, 78, 11-13.

59 C. R. Hammerschmidt and W. F. Fitzgerald, Environ. Sci. Technol., 2006, 40, 7764-7770.

60 D. C. Evers, Y. J. Han, C. T. Driscoll, N. C. Kamman, M. W. Goodale, K. L. Lambert, T. M. Holsen, C. Y. Chen, T. A. Clair and T. Butler, Bioscience, 2007, 57, 29-43.

61 N. J. Bauch, C. J. Schmitt and C. G. Crawford, Development of an Approach for Integrating Components of the U.S. Geological Survey Biomonitoring of Environmental Status and Trends (BEST) and National Stream Quantity Accounting Network (NASQAN) Programs for Large U.S. Rivers, Scientific Investigations Report 2005-5083, U.S. Geological Survey, 2005.

62 E. P. Smith, in Biological Indicators of Aquatic Ecosystem Stress, ed. S. M. Adams, American Fisheries Society, Bethesda, MD, 2002, pp. $565-590$.

63 R. E. Donohoe and L. R. Curtis, Aquat. Toxicol., 1996, 36, 31-52. 
64 J. R. Ungerer and P. Thomas, Aquat. Toxicol., 1996, 35 , 183-195.

65 D. M. Papoulias, S. A. Villalobos, J. Meadows, D. B. Noltie, J. P. Giesy and D. E. Tillitt, Environ. Health Perspect., 2003, 111, 29-32.

66 S. Thompson, F. Tilton, D. Schlenk and W. H. Benson, Mar. Environ. Res., 2000, 51, 185-189.
67 A. S. Friedmann, E. K. Costain, D. L. MacLatchy, W. Stansley and E. J. Washuta, Ecotox. Environ. Saf., 2002, 52, 117-122.

68 E. Noaksson, M. Linderoth, U. Tjarnlund and L. Balk, Aquat. Toxicol., 2005, 75, 162-177.

69 N. Garcia-Reyero, D. S. Barber, T. S. Gross, K. G. Johnson, M. S. Sepulveda, N. J. Szabo and N. D. Denslow, Aquat. Toxicol., 2006, 78, 358-369. 
Supplementary Material (ESI) for Journal of Environmental Monitoring

This journal is (C) The Royal Society of Chemistry 2008

1

2 Supplementary Data

3

4 Table S1. Collection sites and samples sizes for female (F) and male (M) bass and carp.

5 Table S2. Limits of detection (LODs) for organochlorine residues (ng g ${ }^{-1}$ wet weight), 2,3,7,8-

6 tetrachlorodibenzo-p-dioxin equivalent dose (TCDD-EQ; $\mathrm{pg} \mathrm{g}^{-1}$ wet weight), and elemental contaminants ( $\mu \mathrm{g} \mathrm{g}^{-}$

$7 \quad{ }^{1}$ wet weight)

8 Table S3. Cumulative frequency percentile concentrations of organochlorine chemical residues (ng g ${ }^{-1}$ wet

9 weight), TCDD-EQ ( $\mathrm{pg} \mathrm{g}^{-1}$ wet weight), and elemental contaminants ( $\mu \mathrm{g} \mathrm{g}^{-1}$ wet weight) in whole-body fish 10 composite samples.

11 Table S4. Cumulative frequency percentiles of biomarkers in individual fish. 
Supplementary Material (ESI) for Journal of Environmental Monitoring

This journal is (C) The Royal Society of Chemistry 2008

1 Table S1. Collection sites and samples sizes for female (F) and male (M) bass and carp.

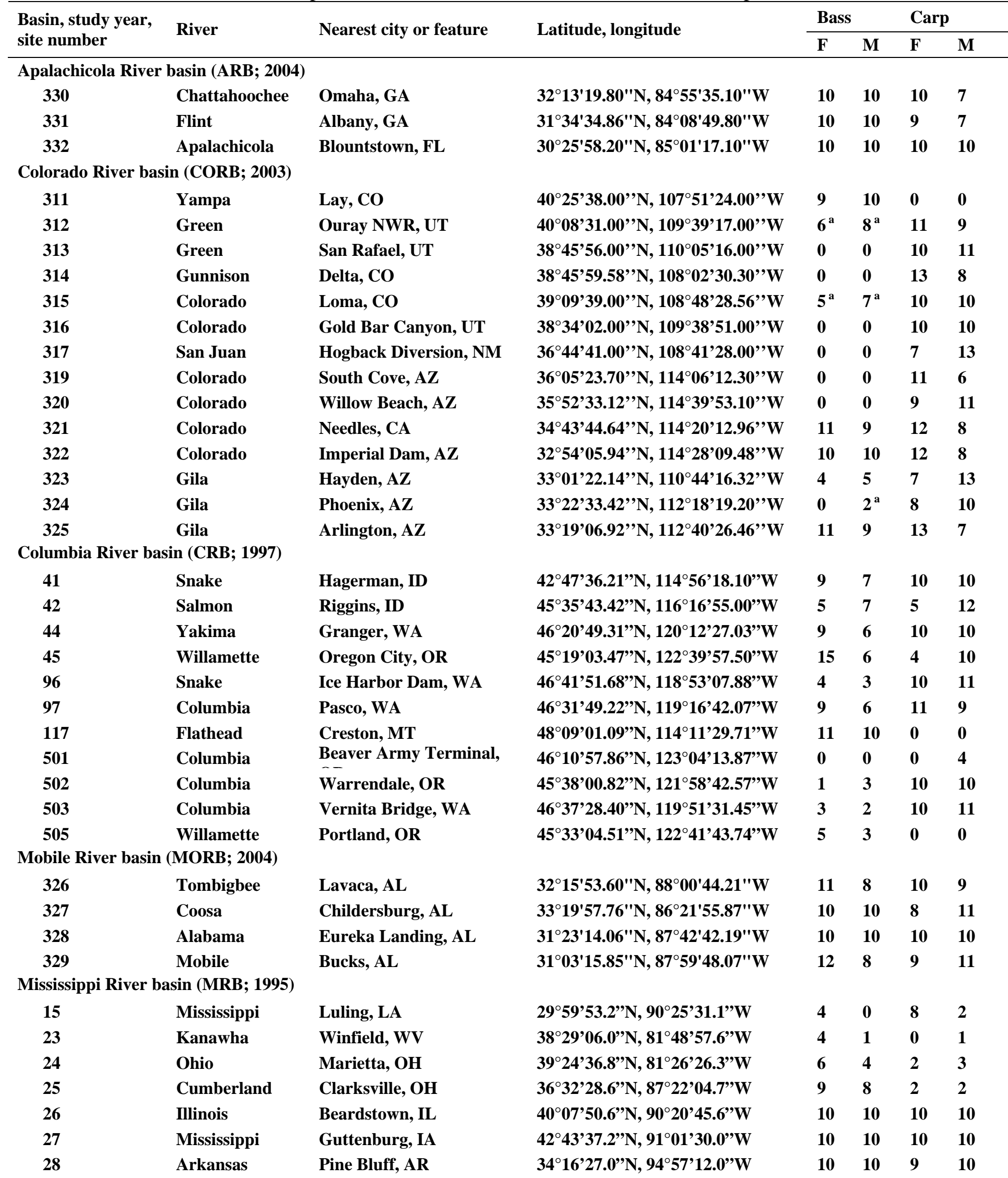


Supplementary Material (ESI) for Journal of Environmental Monitoring This journal is (C) The Royal Society of Chemistry 2008

\begin{tabular}{|c|c|c|c|c|c|c|c|}
\hline \multirow{2}{*}{$\begin{array}{l}\text { Basin, study year, } \\
\text { site number }\end{array}$} & \multirow{2}{*}{ River } & \multirow{2}{*}{ Nearest city or feature } & \multirow{2}{*}{ Latitude, longitude } & \multicolumn{2}{|c|}{ Bass } & \multicolumn{2}{|c|}{ Carp } \\
\hline & & & & $\mathbf{F}$ & $\mathbf{M}$ & $\mathbf{F}$ & $\mathbf{M}$ \\
\hline 29 & Arkansas & Keystone Res., OK & $36^{\circ} 07^{\prime} 54.0 ” \mathrm{~N}, 96^{\circ} 20^{\prime} 47.0^{\prime \prime} \mathrm{W}$ & 7 & 8 & 11 & 9 \\
\hline 30 & White & Devall's Bluff, AR & $34^{\circ} 47^{\prime} 01.0 ” N, 9^{\circ} 26^{\prime} 28.0^{\prime \prime} \mathrm{W}$ & 10 & 9 & 7 & 10 \\
\hline 31 & Missouri & Nebraska City, NE & $40^{\circ} 40^{\prime} 15.9^{\prime \prime} \mathrm{N}, 9^{\circ} 49^{\prime} 44.6^{\prime \prime} \mathrm{W}$ & $\mathbf{0}$ & $\mathbf{0}$ & 12 & 11 \\
\hline 32 & Missouri & Garrison Dam, ND & $4^{\circ} 28^{\prime} 27.3^{\prime \prime} \mathrm{N}, 1^{\circ} 26^{\prime} 15.5^{\prime} \mathrm{W}$ & 1 & $\mathbf{0}$ & 9 & 11 \\
\hline 67 & Allegheny & Natrona, PA & $40^{\circ} 39^{\prime} 54.0^{\prime \prime} \mathrm{N}, 7^{\circ} 41^{\prime} 24.0 ” \mathrm{~W}$ & 9 & 4 & 6 & 5 \\
\hline 68 & Wabash & New Harmony, IN & $38^{\circ} 11^{\prime} 58.4 ” N, 8^{\circ} 58^{\prime} 36.0 ” W$ & 5 & 6 & 9 & 8 \\
\hline 70 & Ohio & Metropolis, IL & $37^{\circ} 07^{\prime} 40.8 ” \mathrm{~N}, 8^{\circ} 39^{\prime} 25.2^{\prime \prime} \mathrm{W}$ & 9 & 14 & 5 & 6 \\
\hline 71 & Tennessee & Savannah, TN & $35^{\circ} 12^{\prime} 52.0^{\prime \prime} \mathrm{N}, 8^{\circ} 18 ’ 36.0^{\prime \prime} \mathrm{W}$ & 3 & 9 & 5 & 10 \\
\hline 72 & Wisconsin & Woodman, WI & $43^{\circ} 05^{\prime} 42.0^{\prime \prime} \mathrm{N}, 9^{\circ} 48^{\prime} 57.6^{\prime \prime} \mathrm{W}$ & 12 & 4 & 10 & 12 \\
\hline 73 & Des Moines & Keosauqua, IA & $40^{\circ} 44^{\prime} 52.8^{\prime \prime} \mathrm{N}, 9^{\circ} 59^{\prime} 38.4^{\prime \prime} \mathrm{W}$ & $\mathbf{0}$ & $\mathbf{0}$ & 10 & 10 \\
\hline 74 & Mississippi & Little Falls, MN & $45^{\circ} 58^{\prime} 48.0^{\prime \prime} \mathrm{N}, 9^{\circ} 22^{\prime} 00.0^{\prime \prime} \mathrm{W}$ & 10 & 7 & $\mathbf{0}$ & $\mathbf{0}$ \\
\hline 75 & Mississippi & Cape Girardeau, MO & 37¹8’36.0”N, 89³1’01.2”W & $\mathbf{0}$ & $\mathbf{0}$ & 10 & 10 \\
\hline 76 & Mississippi & Memphis, TN & $38^{\circ} 08^{\prime} 30.3 ” \mathrm{~N}, 9^{\circ} 03^{\prime} 36.6^{\prime \prime} \mathrm{W}$ & 10 & 8 & 9 & 8 \\
\hline 77 & Arkansas & John Martin Res., CO & $38^{\circ} 03^{\prime} 55.0^{\prime \prime} \mathrm{N}, 1^{\circ}{ }^{\circ} 56^{\prime} 02.0^{\prime \prime} \mathrm{W}$ & 8 & 10 & 11 & 7 \\
\hline 78 & Verdigris & Oolagah, OK & 36³1’16.0”N, 95³3’37.0”W & 10 & 9 & 10 & 9 \\
\hline 79 & Canadian & Eufaula, OK & $35^{\circ} 16^{\prime} 43.0^{\prime \prime} \mathrm{N}, 9^{\circ} 34^{\prime} 39.0^{\prime \prime} \mathrm{W}$ & 12 & 10 & 10 & 10 \\
\hline 80 & Yazoo & Redwood, MS & $32^{\circ} 24^{\prime} 36.0 ” \mathrm{~N}, 90^{\circ} 55^{\prime} 27.0 ” \mathrm{~W}$ & 2 & 1 & 5 & 7 \\
\hline 81 & Red & Alexandria, LA & $31^{\circ} 20^{\prime} 48.0 ” \mathrm{~N}, 9^{\circ} 27^{\prime} 37.0 ” \mathrm{~W}$ & 17 & 7 & 8 & 4 \\
\hline 82 & Red & Lake Texoma, TX/OK & $33^{\circ} 52^{\prime} 08.0 ” N, 9^{\circ} 47^{\prime} 04.0^{\prime \prime} \mathrm{W}$ & 13 & 13 & 13 & 11 \\
\hline 83 & Missouri & Hermann, MO & $38^{\circ} 42^{\prime} 24.1^{\prime \prime} \mathrm{N}, 9^{\circ} 26^{\prime} 17.5^{\prime \prime} \mathrm{W}$ & 8 & 9 & 6 & 9 \\
\hline 84 & Big Horn & Hardin, MT & 4552'12.2”'N, 107³4’34.0”W & $\mathbf{0}$ & $\mathbf{0}$ & 12 & 8 \\
\hline 85 & Yellowstone & Sidney, NE & 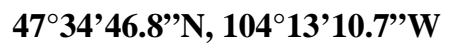 & $\mathbf{0}$ & $\mathbf{0}$ & 12 & 8 \\
\hline 86 & James & Olivet, SD & $43^{\circ} 13^{\prime} 45.0^{\prime \prime} \mathrm{N}, 9^{\circ} 41^{\prime} 05.0 ” \mathrm{~W}$ & $\mathbf{0}$ & $\mathbf{0}$ & 10 & 10 \\
\hline 89 & Platte & Louisville, NE & $40^{\circ} 59^{\prime} 33.1 ” N, 96^{\circ} 12^{\prime} 30.9 ” W$ & $\mathbf{0}$ & $\mathbf{0}$ & 2 & 7 \\
\hline 90 & Kansas & Bonner Springs, KS & 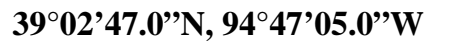 & $\mathbf{0}$ & $\mathbf{0}$ & 10 & 10 \\
\hline 111 & Mississippi & Lake City, MN & $44^{\circ} 22^{\prime} 49.8 ” \mathrm{~N}, 9^{\circ} 07^{\prime} 33.0 ” \mathrm{~W}$ & 11 & 11 & 10 & 10 \\
\hline 112 & Mississippi & Dubuque, IA & $42^{\circ} 26^{\prime} 27.6 ” \mathrm{~N}, 90^{\circ} 35^{\prime} 06.0 ” \mathrm{~W}$ & 10 & 10 & 10 & 10 \\
\hline 201 & Big Sunflower & Anguilla, MS & $32^{\circ} 58 ' 18.0 ” \mathrm{~N}, 90^{\circ} 46^{\prime} 40.0^{\prime \prime} \mathrm{W}$ & $\mathbf{0}$ & $\mathbf{0}$ & 9 & 8 \\
\hline 202 & Bogue Phalia & Leland, MS & $33^{\circ} 24^{\prime} 22.0 ” \mathrm{~N}, 90^{\circ} 50^{\prime} 26.0 ” \mathrm{~W}$ & $\mathbf{0}$ & $\mathbf{0}$ & 10 & 10 \\
\hline 203 & Steele Bayou & Rolling Fork, MS & $32^{\circ} 54^{\prime} 71.0 ” \mathrm{~N}, 90^{\circ} 57^{\prime} 10.0 ” \mathrm{~W}$ & $\mathbf{0}$ & $\mathbf{0}$ & 8 & 10 \\
\hline 204 & Tensas & Tendal, LA & $32^{\circ} 25^{\prime} 56.0 ” \mathrm{~N}, 9^{\circ} 21^{\prime} 57.0^{\prime \prime} \mathrm{W}$ & $\mathbf{0}$ & $\mathbf{0}$ & 5 & 10 \\
\hline 205 & S. Skunk & Oskaloosa, IA & $41^{\circ} 21^{\prime} 19.0 ” \mathrm{~N}, 92^{\circ} 39^{\prime} 31.0 ” \mathrm{~W}$ & $\mathbf{0}$ & $\mathbf{0}$ & 10 & 10 \\
\hline 206 & Iowa & Morengo, IA & 41 50 '23.0”'N, 92 ${ }^{\circ} 11^{\prime} 54.0 ” \mathrm{~W}$ & $\mathbf{0}$ & $\mathbf{0}$ & 10 & 10 \\
\hline 207 & Cache & Cotton Plant, AR & $35^{\circ} 02^{\prime} 32.0^{\prime \prime} \mathrm{N}, 9^{\circ} 19^{\prime} 12.0^{\prime \prime} \mathrm{W}$ & $\mathbf{0}$ & $\mathbf{0}$ & 8 & 10 \\
\hline 208 & Cache & Egypt, AR & $35^{\circ} 51^{\prime} 23.0 ” \mathrm{~N}, 90^{\circ} 56^{\prime} 15.0 ” \mathrm{~W}$ & $\mathbf{0}$ & $\mathbf{0}$ & 10 & 10 \\
\hline 209 & S. Fork Iowa & New Providence, IA & $42^{\circ} 19^{\prime} 26.0 ” \mathrm{~N}, 93^{\circ} 10^{\prime} 10.0^{\prime \prime} \mathrm{W}$ & $\mathbf{0}$ & $\mathbf{0}$ & 3 & 5 \\
\hline 210 & Iowa & Rowan, IA & $42^{\circ} 45^{\prime} 36.0 ” N, 9^{\circ} 37^{\prime} 23.0 ” \mathrm{~W}$ & $\mathbf{0}$ & $\mathbf{0}$ & 10 & 10 \\
\hline 211 & Cedar & St. Charles City, IA & $43^{\circ} 03^{\prime} 45.0^{\prime \prime} \mathrm{N}, 92^{\circ} 40^{\prime} 23.0^{\prime \prime} \mathrm{W}$ & $\mathbf{0}$ & $\mathbf{0}$ & 10 & 10 \\
\hline 212 & Little R. Ditch & Moorehouse, MO & $36^{\circ} 50^{\prime} 03.0 ” \mathrm{~N}, 8^{\circ} 43^{\prime} 48.0^{\prime \prime} \mathrm{W}$ & 1 & 2 & 10 & 10 \\
\hline 213 & Wolf & LaGrange, TN & $35^{\circ} 01{ }^{\prime} 57.0 ” \mathrm{~N}, 8^{\circ} 14^{\prime} 48.0$ ' W & 4 & 7 & $\mathbf{0}$ & $\mathbf{0}$ \\
\hline $400^{b}$ & Leetown Res. & Kearneysville, WV & $39^{\circ} 21^{\prime} 2.15^{\prime} \mathrm{N}, 7^{\circ} 55^{\prime} 32.69^{\prime} \mathrm{W}$ & 10 & 10 & 8 & 11 \\
\hline \multicolumn{8}{|c|}{ Pee Dee River basin (PRB; 2004) } \\
\hline 336 & Pee Dee & Rockingham, NC & $34^{\circ} 53 ' 22.14^{\prime \prime N}, 79^{\circ} 51 ' 24.89 " \mathrm{~W}$ & 3 & 3 & 1 & $\mathbf{0}$ \\
\hline 337 & Pee Dee & Pee Dee, SC & $34^{\circ} 21^{\prime} 23.22^{\prime \prime N}, 79^{\circ} 41^{\prime} 35.19^{\prime \prime} \mathrm{W}$ & 11 & 11 & 7 & 10 \\
\hline 338 & Pee Dee & Bucksport, SC & $33^{\circ} 42^{\prime} 18.09 " \mathrm{~N}, 7^{\circ} 11^{\prime} 24.00^{\prime \prime} \mathrm{W}$ & 10 & 11 & 2 & 2 \\
\hline
\end{tabular}


Supplementary Material (ESI) for Journal of Environmental Monitoring This journal is (C) The Royal Society of Chemistry 2008

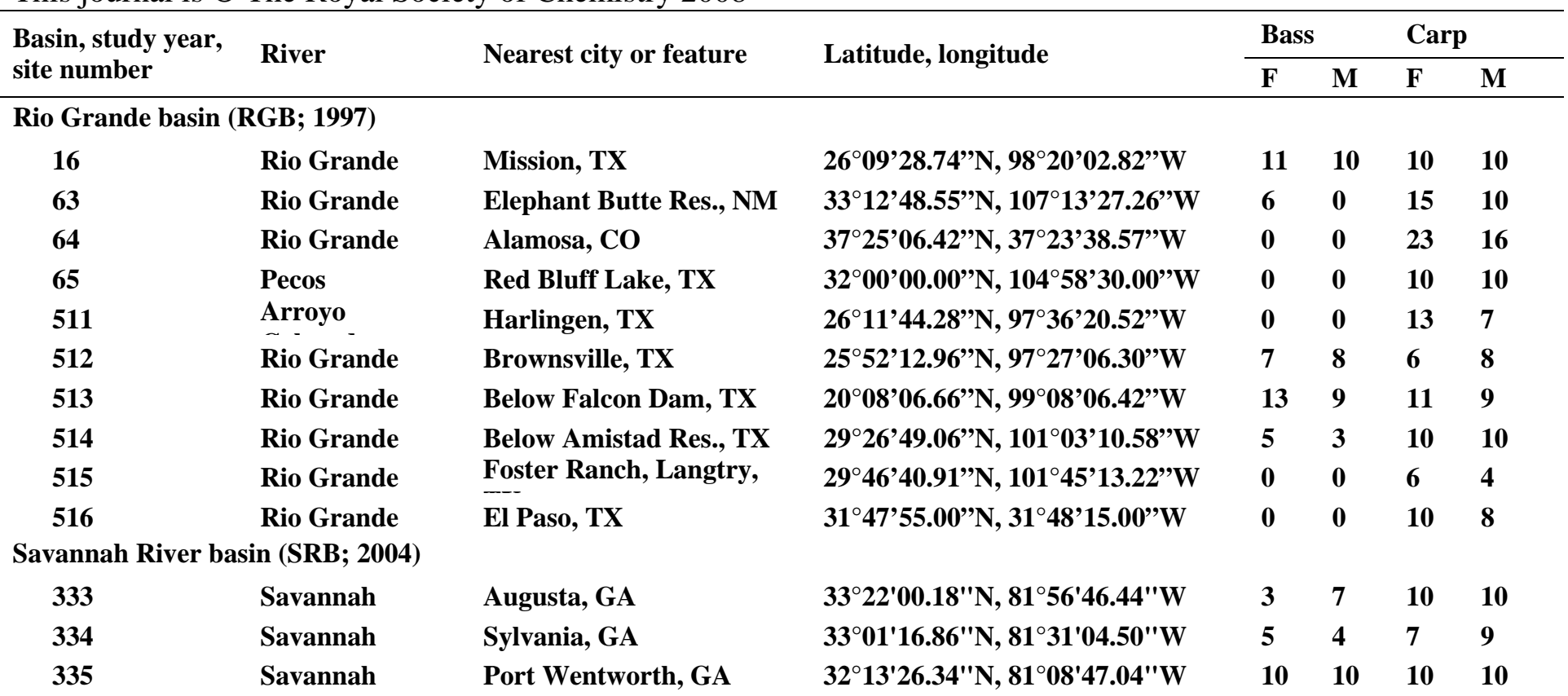

See http://www.cerc.usgs.gov/data/best/search/ for individual fish included in each composite sample. ${ }^{\text {a }}$ Chemical contaminant data not available. ${ }^{b}$ Reference site in original study. ${ }^{15}$ 
Supplementary Material (ESI) for Journal of Environmental Monitoring

This journal is (C) The Royal Society of Chemistry 2008

1 Table S2. Limits of detection for organochlorine residues (ng g ${ }^{-1}$ wet weight), 2,3,7,8-tetrachlorodibenzo-p-dioxin

2 equivalent dose (TCDD-EQ; pg g $^{-1}$ wet weight), and elemental contaminants ( $\mu \mathrm{g} \mathrm{g}^{-1}$ wet weight)

\begin{tabular}{|c|c|c|c|c|}
\hline Contaminant & $\begin{array}{l}\text { Mississippi } \\
\text { River basin } \\
\text { (1995) } \\
\end{array}$ & $\begin{array}{c}\text { Rio Grande and } \\
\text { Columbia River } \\
\text { basins (1997) } \\
\end{array}$ & $\begin{array}{c}\text { Colorado } \\
\text { River basin } \\
(2003) \\
\end{array}$ & $\begin{array}{l}\text { Mobile, Apalachicola, } \\
\text { Savannah, and Pee Dee } \\
\text { River basins (2004) }\end{array}$ \\
\hline \multicolumn{5}{|c|}{ Organochlorine residue and TCDD-EQ } \\
\hline Pentachlorobenzene & NM & NM & 0.07 & 0.07 \\
\hline Hexachlorobenzene & 10.0 & 10.0 & 0.26 & 0.14 \\
\hline Pentachloroanisole & NM & NM & 0.13 & 0.10 \\
\hline$\alpha-\mathrm{HCH}$ & 10.0 & 10.0 & 0.08 & 0.10 \\
\hline$\beta-\mathrm{HCH}$ & 10.0 & 10.0 & 0.19 & 0.30 \\
\hline$\gamma-\mathrm{HCH}$ & 10.0 & 10.0 & 0.51 & 0.10 \\
\hline$\delta-\mathrm{HCH}$ & 10.0 & 10.0 & 0.05 & 0.10 \\
\hline Aldrin & NM & NM & 0.27 & 0.09 \\
\hline Dieldrin & 10.0 & 10.0 & 0.15 & 0.08 \\
\hline Endrin & 10.0 & 10.0 & 0.10 & 0.25 \\
\hline Dacthal & NM & NM & 0.50 & 0.13 \\
\hline Heptachlor & NM & NM & 0.19 & 0.10 \\
\hline Heptachlor epoxide & 10.0 & 10.0 & 0.01 & 0.10 \\
\hline Oxychlordane & 10.0 & 10.0 & 0.08 & 0.10 \\
\hline cis-Chlordane & 10.0 & 10.0 & 0.04 & 0.28 \\
\hline trans-Chlordane & 10.0 & 10.0 & 0.23 & 0.15 \\
\hline cis-Nonachlor & 10.0 & 10.0 & 0.10 & 0.10 \\
\hline trans-Nonachlor & 10.0 & 10.0 & 0.03 & 0.09 \\
\hline$o, p^{\prime}-\mathrm{DDE}$ & 10.0 & 10.0 & 0.08 & 0.81 \\
\hline$o, p$-DDD & 10.0 & 10.0 & 0.55 & 0.10 \\
\hline$o, p$ '-DDT & 10.0 & 10.0 & 0.53 & 0.10 \\
\hline$p, p$ '-DDE & 10.0 & 10.0 & 0.86 & 2.4 \\
\hline$p, p$-DDD & 10.0 & 10.0 & 0.67 & 0.18 \\
\hline$p, p$-DDT & 10.0 & 10.0 & 1.4 & 0.47 \\
\hline Endosulfan I & NM & NM & 0.21 & 0.10 \\
\hline Endosulfan II & NM & NM & 0.17 & 0.10 \\
\hline Endosulfan sulfate & NM & NM & 0.05 & 0.14 \\
\hline Methoxychlor & NM & NM & 0.35 & 0.10 \\
\hline Mirex & 10.0 & 10.0 & 0.05 & 0.10 \\
\hline Polychlorinated biphenyls & 50 & 30 & 48 & 61 \\
\hline Toxaphene & 50 & 30 & 24 & 10 \\
\hline TCDD-EQ & $0.2-1.0$ & $0.4-1.3$ & $0.1-0.5$ & $1.0-2.6$ \\
\hline \multicolumn{5}{|l|}{ Elemental contaminant } \\
\hline Arsenic & $0.11-0.27$ & $0.03-0.32$ & NA & 0.01 \\
\hline
\end{tabular}


Supplementary Material (ESI) for Journal of Environmental Monitoring This journal is (C) The Royal Society of Chemistry 2008

$\begin{array}{lcccc}\text { Barium } & 0.16-0.21 & 0.27-0.31 & 0.29-0.33 & \text { NA } \\ \text { Cadmium } & 0.02-0.05 & 0.02-0.06 & 0.02-0.03 & 0.01 \\ \text { Chromium } & 0.16 & \text { NA } & 0.24-0.35 & \text { NA } \\ \text { Copper } & \text { NA } & \text { NA } & \text { NA } & \text { NA } \\ \text { Mercury } & 0.04-0.05 & 0.02-0.06 & \text { NA } & \text { NA } \\ \text { Magnesium } & \text { NA } & \text { NA } & \text { NA } & \text { NA } \\ \text { Manganese } & \text { NA } & \text { NA } & \text { NA } & \text { NA } \\ \text { Molybdenum } & 0.11-0.27 & 0.10-0.34 & 0.24-0.35 & 0.01 \\ \text { Nickel } & 0.16-0.26 & 0.22-0.33 & 0.24-0.35 & 0.01 \\ \text { Lead } & 0.01-0.04 & 0.03-0.14 & 0.24-0.35 & 0.01 \\ \text { Selenium } & 0.12-0.18 & 0.22-0.27 & \text { NA } & \text { NA } \\ \text { Strontium } & \text { NA } & \text { NA } & \text { NA } & \text { NA } \\ \text { Vanadium } & 0.11-0.27 & 0.10-0.31 & \text { NA } & \text { NA } \\ \text { Zinc } & \text { NA } & \text { NA } & \text { NA } & \text { NA } \\ & & & & \end{array}$

Study year is shown in parentheses. HCH, hexachlorocyclohexane; NM, analyte not measured; NA, all concentrations were $>$ LOD. 
Supplementary Material (ESI) for Journal of Environmental Monitoring

This journal is (C) The Royal Society of Chemistry 2008

1 Table S3. Cumulative frequency percentile concentrations of organochlorine chemical residues (ng g ${ }^{-1}$ wet weight),

2 TCDD-EQ ( pg g $^{-1}$ wet weight), and elemental contaminants ( $\mu \mathrm{g} \mathrm{g}^{-1}$ wet weight) in whole-body fish composite samples.

\begin{tabular}{|c|c|c|c|c|c|c|c|c|c|c|c|c|}
\hline \multirow{2}{*}{ Contaminant } & \multicolumn{6}{|l|}{ Bass } & \multicolumn{6}{|l|}{ Carp } \\
\hline & $10^{\text {th }}$ & $25^{\text {th }}$ & $50^{\text {th }}$ & $75^{\text {th }}$ & $90^{\text {th }}$ & $100^{\text {th }}$ & $10^{\text {th }}$ & $25^{\text {th }}$ & $50^{\text {th }}$ & $75^{\text {th }}$ & $90^{\text {th }}$ & $100^{\text {th }}$ \\
\hline \multicolumn{13}{|c|}{ Pentachlorobenzene $^{\mathrm{a}}$} \\
\hline Female & 0.04 & 0.04 & 0.04 & 0.14 & 0.45 & 0.60 & 0.04 & 0.04 & 0.09 & 0.18 & 0.41 & 1.19 \\
\hline Male & 0.04 & 0.04 & 0.04 & 0.09 & 0.32 & 0.35 & 0.04 & 0.04 & 0.13 & 0.21 & 0.55 & 0.89 \\
\hline \multicolumn{13}{|c|}{ Hexachlorobenzene } \\
\hline Female & 0.31 & 0.76 & 5.00 & 5.00 & 5.00 & 5.00 & 0.46 & 2.40 & 5.00 & 5.00 & 5.00 & 20.0 \\
\hline Male & 0.32 & 0.55 & 5.00 & 5.00 & 5.00 & 32.0 & 0.57 & 0.25 & 5.00 & 5.00 & 5.00 & 68.0 \\
\hline \multicolumn{13}{|c|}{ Pentachloroanisole ${ }^{a}$} \\
\hline Female & 0.05 & 0.05 & 0.23 & 0.34 & 0.57 & 1.90 & 0.48 & 0.82 & 1.40 & 2.60 & 3.14 & 5.60 \\
\hline Male & 0.05 & 0.14 & 0.22 & 0.43 & 0.62 & 1.00 & 0.46 & 0.90 & 1.72 & 3.45 & 9.41 & 21.0 \\
\hline \multicolumn{13}{|l|}{ Aldrin $^{\mathrm{a}}$} \\
\hline Female & 0.05 & 0.05 & 0.05 & 0.14 & 0.14 & 0.14 & 0.05 & 0.05 & 0.14 & 0.14 & 0.14 & 0.18 \\
\hline Male & 0.05 & 0.05 & 0.05 & 0.14 & 0.18 & 0.20 & 0.05 & 0.05 & 0.14 & 0.14 & 0.14 & 0.19 \\
\hline \multicolumn{13}{|l|}{ Dieldrin } \\
\hline Female & 1.10 & 4.36 & 5.00 & 5.00 & 18.0 & 76.0 & 1.03 & 5.00 & 5.00 & 12.0 & 41.5 & 250 \\
\hline Male & 0.95 & 3.17 & 5.00 & 5.00 & 17.0 & 67.0 & 0.95 & 5.00 & 5.00 & 16.6 & 50.5 & 130 \\
\hline \multicolumn{13}{|l|}{ Endrin } \\
\hline Female & 0.13 & 0.32 & 5.00 & 5.00 & 5.00 & 220 & 0.13 & 2.67 & 5.00 & 5.00 & 5.00 & 710 \\
\hline Male & 0.13 & 0.54 & 5.00 & 5.00 & 5.00 & 220 & 0.13 & 4.70 & 5.00 & 5.00 & 5.00 & 400 \\
\hline \multicolumn{13}{|l|}{$\alpha-\mathrm{HCH}$} \\
\hline Female & 0.05 & 0.08 & 5.00 & 5.00 & 5.00 & 5.00 & 0.05 & 0.27 & 5.00 & 5.00 & 5.00 & 5.00 \\
\hline Male & 0.05 & 0.29 & 5.00 & 5.00 & 5.00 & 5.00 & 0.05 & 0.05 & 5.00 & 5.00 & 5.00 & 5.00 \\
\hline \multicolumn{13}{|l|}{$\beta-\mathrm{HCH}$} \\
\hline Female & 0.15 & 0.38 & 5.00 & 5.00 & 5.00 & 5.00 & 0.15 & 1.76 & 5.00 & 5.00 & 5.00 & 5.00 \\
\hline Male & 0.15 & 0.36 & 5.00 & 5.00 & 5.00 & 5.00 & 0.15 & 2.19 & 5.00 & 5.00 & 5.00 & 5.00 \\
\hline \multicolumn{13}{|l|}{$\gamma-\mathrm{HCH}$} \\
\hline Female & 0.05 & 0.26 & 5.00 & 5.00 & 5.00 & 5.00 & 0.05 & 0.91 & 5.00 & 5.00 & 5.00 & 5.00 \\
\hline Male & 0.05 & 0.26 & 5.00 & 5.00 & 5.00 & 5.00 & 0.05 & 1.33 & 5.00 & 5.00 & 5.00 & 5.00 \\
\hline \multicolumn{13}{|l|}{$\delta$-HCH } \\
\hline Female & 0.05 & 0.07 & 5.00 & 5.00 & 5.00 & 5.00 & 0.05 & 0.18 & 5.00 & 5.00 & 5.00 & 5.00 \\
\hline Male & 0.05 & 0.05 & 5.00 & 5.00 & 5.00 & 5.00 & 0.05 & 0.15 & 5.00 & 5.00 & 5.00 & 5.00 \\
\hline \multicolumn{13}{|l|}{ Dacthal $^{\text {a }}$} \\
\hline Female & 0.07 & 0.07 & 0.15 & 0.25 & 0.65 & 2.58 & 0.07 & 0.07 & 0.25 & 0.63 & 1.06 & 5.45 \\
\hline Male & 0.07 & 0.07 & 0.15 & 0.25 & 0.70 & 2.62 & 0.07 & 0.07 & 0.25 & 0.73 & 1.20 & 9.28 \\
\hline
\end{tabular}

Heptachlor $^{\text {a }}$ 
Supplementary Material (ESI) for Journal of Environmental Monitoring

This journal is (C) The Royal Society of Chemistry 2008

\begin{tabular}{|c|c|c|c|c|c|c|c|c|c|c|c|c|}
\hline \multirow{2}{*}{ Contaminant } & \multicolumn{6}{|l|}{ Bass } & \multicolumn{6}{|l|}{ Carp } \\
\hline & $10^{\text {th }}$ & $25^{\text {th }}$ & $50^{\text {th }}$ & $75^{\text {th }}$ & $90^{\text {th }}$ & $100^{\text {th }}$ & $10^{\text {th }}$ & $25^{\text {th }}$ & $50^{\text {th }}$ & $75^{\text {th }}$ & $90^{\text {th }}$ & $100^{\text {th }}$ \\
\hline Female & 0.05 & 0.05 & 0.05 & 0.10 & 0.58 & 0.83 & 0.05 & 0.05 & 0.07 & 0.10 & 0.10 & 0.10 \\
\hline Male & 0.05 & 0.05 & 0.05 & 0.10 & 0.10 & 0.98 & 0.05 & 0.05 & 0.10 & 0.10 & 0.21 & 0.28 \\
\hline \multicolumn{13}{|c|}{ Heptachlor epoxide } \\
\hline Female & 0.27 & 1.09 & 5.00 & 5.00 & 5.00 & 5.00 & 0.30 & 1.68 & 5.00 & 5.00 & 5.00 & 34.0 \\
\hline Male & 0.22 & 0.93 & 5.00 & 5.00 & 5.00 & 10.0 & 0.28 & 3.61 & 5.00 & 5.00 & 5.00 & 75.0 \\
\hline \multicolumn{13}{|l|}{ Oxychlordane } \\
\hline Female & 0.55 & 2.80 & 5.00 & 5.00 & 5.00 & 6.00 & 0.29 & 2.26 & 5.00 & 5.00 & 5.00 & 15.0 \\
\hline Male & 0.49 & 1.85 & 5.00 & 5.00 & 5.00 & 5.00 & 0.20 & 3.25 & 5.00 & 5.00 & 5.00 & 28.0 \\
\hline \multicolumn{13}{|l|}{ cis-Chlordane } \\
\hline Female & 0.97 & 5.00 & 5.00 & 5.00 & 13.0 & 57.0 & 1.70 & 5.00 & 5.00 & 10.0 & 21.5 & 120 \\
\hline Male & 0.54 & 5.00 & 5.00 & 5.00 & 12.0 & 35.0 & 2.03 & 5.00 & 5.00 & 11.0 & 28.0 & 91.0 \\
\hline \multicolumn{13}{|c|}{ trans-Chlordane } \\
\hline Female & 0.27 & 1.68 & 5.00 & 5.00 & 5.00 & 69.0 & 0.99 & 5.00 & 5.00 & 5.00 & 14.0 & 350 \\
\hline Male & 0.35 & 1.36 & 5.00 & 5.00 & 5.00 & 47.0 & 0.91 & 5.00 & 5.00 & 5.00 & 17.0 & 190 \\
\hline \multicolumn{13}{|l|}{ cis-Nonachlor } \\
\hline Female & 1.09 & 5.00 & 5.00 & 5.00 & 5.64 & 33.0 & 1.15 & 3.89 & 5.00 & 5.00 & 5.47 & 35.0 \\
\hline Male & 1.11 & 5.00 & 5.00 & 5.00 & 12.0 & 25.0 & 0.98 & 5.00 & 5.00 & 5.00 & 13.0 & 31.0 \\
\hline \multicolumn{13}{|c|}{ trans-Nonachlor } \\
\hline Female & 1.42 & 5.00 & 5.00 & 12.0 & 22.0 & 77.0 & 1.79 & 5.00 & 5.00 & 13.0 & 26.0 & 91.0 \\
\hline Male & 2.34 & 5.00 & 5.00 & 12.0 & 29.0 & 310 & 1.92 & 5.00 & 6.69 & 17.0 & 43.1 & 100 \\
\hline \multicolumn{13}{|l|}{$o, p^{\prime}-\mathrm{DDE}$} \\
\hline Female & 0.41 & 1.42 & 5.00 & 5.00 & 5.00 & 13.0 & 0.41 & 3.22 & 5.00 & 5.00 & 5.00 & 22.0 \\
\hline Male & 0.41 & 2.00 & 5.00 & 5.00 & 5.00 & 17.0 & 1.01 & 5.00 & 5.00 & 5.00 & 5.00 & 14.3 \\
\hline \multicolumn{13}{|l|}{$o, p^{\prime}-\mathrm{DDD}$} \\
\hline Female & 0.28 & 1.19 & 5.00 & 5.00 & 5.00 & 320 & 0.28 & 3.77 & 5.00 & 5.00 & 15.0 & 340 \\
\hline Male & 0.28 & 0.87 & 5.00 & 5.00 & 5.00 & 15.0 & 0.42 & 4.10 & 5.00 & 5.00 & 7.39 & 250 \\
\hline \multicolumn{13}{|l|}{$o, p^{\prime}-\mathrm{DDT}$} \\
\hline Female & 0.05 & 0.46 & 5.00 & 5.00 & 5.00 & 240 & 0.05 & 1.10 & 5.00 & 5.00 & 5.00 & 110 \\
\hline Male & 0.05 & 0.27 & 5.00 & 5.00 & 5.00 & 13.0 & 0.05 & 1.55 & 5.00 & 5.00 & 5.00 & 51.0 \\
\hline \multicolumn{13}{|l|}{$p, p^{\prime}-\mathrm{DDE}$} \\
\hline Female & 6.90 & 15.6 & 41.0 & 170 & 360 & 1600 & 10.0 & 21.0 & 52.7 & 210 & 560 & 4200 \\
\hline Male & 8.66 & 17.0 & 42.0 & 130 & 280 & 2700 & 11.8 & 23.0 & 68.0 & 280 & 680 & 8300 \\
\hline \multicolumn{13}{|l|}{$p, p^{\prime}-\mathrm{DDD}$} \\
\hline Female & 1.90 & 5.00 & 5.00 & 19.0 & 40.0 & 280 & 3.10 & 5.00 & 10.2 & 28.0 & 79.0 & 1200 \\
\hline Male & 2.70 & 5.00 & 5.00 & 15.0 & 32.0 & 160 & 3.45 & 5.00 & 14.0 & 32.0 & 89.5 & 2800 \\
\hline \multicolumn{13}{|l|}{$p, p '-\mathrm{DDT}$} \\
\hline Female & 0.70 & 5.00 & 5.00 & 5.00 & 17.0 & 140 & 0.70 & 3.10 & 5.00 & 5.00 & 5.00 & 18.0 \\
\hline
\end{tabular}


Supplementary Material (ESI) for Journal of Environmental Monitoring

This journal is (C) The Royal Society of Chemistry 2008

\begin{tabular}{|c|c|c|c|c|c|c|c|c|c|c|c|c|}
\hline \multirow{2}{*}{ Contaminant } & \multicolumn{6}{|l|}{ Bass } & \multicolumn{6}{|l|}{ Carp } \\
\hline & $10^{\text {th }}$ & $25^{\text {th }}$ & $50^{\text {th }}$ & $75^{\text {th }}$ & $90^{\text {th }}$ & $100^{\text {th }}$ & $10^{\text {th }}$ & $25^{\text {th }}$ & $50^{\text {th }}$ & $75^{\text {th }}$ & $90^{\text {th }}$ & $100^{\text {th }}$ \\
\hline Male & 0.79 & 3.27 & 5.00 & 5.00 & 12.0 & 120 & 0.70 & 5.00 & 5.00 & 5.00 & 5.00 & 38.0 \\
\hline Endosulfan I ${ }^{\mathrm{a}}$ & & & & & & & & & & & & \\
\hline Female & 0.05 & 0.05 & 0.05 & 0.11 & 0.11 & 0.45 & 0.05 & 0.05 & 0.08 & 0.11 & 0.64 & 3.90 \\
\hline Male & 0.05 & 0.05 & 0.05 & 0.11 & 0.11 & 0.11 & 0.05 & 0.05 & 0.11 & 0.11 & 0.74 & 2.40 \\
\hline
\end{tabular}

Endosulfan II ${ }^{\mathrm{a}}$

$\begin{array}{lllllllllllll}\text { Female } & 0.05 & 0.05 & 0.05 & 0.15 & 0.79 & 44.0 & 0.05 & 0.05 & 0.09 & 0.34 & 0.60 & 51.0 \\ \text { Male } & 0.05 & 0.05 & 0.09 & 0.22 & 0.59 & 25.0 & 0.05 & 0.05 & 0.25 & 0.45 & 5.20 & 54.0\end{array}$

Endosulfan sulfate ${ }^{\mathrm{a}}$

$\begin{array}{lllllllllllll}\text { Female } & 0.07 & 0.07 & 0.07 & 0.52 & 1.13 & 32.0 & 0.18 & 0.35 & 0.86 & 2.36 & 5.27 & 21.0 \\ \text { Male } & 0.07 & 0.07 & 0.07 & 0.46 & 0.72 & 76.0 & 0.20 & 0.34 & 0.95 & 3.70 & 6.20 & 79.0\end{array}$

Methoxychlor $^{\text {a }}$

$\begin{array}{lllllllllllll}\text { Female } & 0.05 & 0.05 & 0.05 & 0.18 & 0.18 & 1.80 & 0.05 & 0.05 & 0.11 & 0.18 & 0.18 & 3.10 \\ \text { Male } & 0.05 & 0.05 & 0.05 & 0.18 & 0.18 & 9.60 & 0.05 & 0.05 & 0.10 & 0.18 & 0.52 & 1.90\end{array}$

Mirex

$\begin{array}{lllllllllllll}\text { Female } & 0.12 & 5.00 & 5.00 & 5.00 & 6.49 & 21.0 & 0.24 & 5.00 & 5.00 & 5.00 & 5.00 & 42.0 \\ \text { Male } & 0.46 & 5.00 & 5.00 & 5.00 & 6.35 & 21.0 & 0.34 & 5.00 & 5.00 & 5.00 & 5.00 & 75.0\end{array}$

Toxaphene

$\begin{array}{lllllllllllll}\text { Female } & 12 & 15 & 25 & 25 & 30 & 740 & 12 & 20 & 25 & 25 & 61 & 2700 \\ \text { Male } & 12 & 15 & 25 & 25 & 30 & 870 & 12 & 20 & 25 & 25 & 65 & 8300\end{array}$

Total PCB

$\begin{array}{lllllllllllll}\text { Female } & 24 & 25 & 110 & 330 & 550 & 1900 & 25 & 25 & 64 & 200 & 470 & 2300 \\ \text { Male } & 24 & 25 & 110 & 380 & 770 & 2700 & 23 & 25 & 97 & 390 & 735 & 3300\end{array}$

TCDD-EQ

$\begin{array}{lllllllllllll}\text { Female } & 0.2 & 0.5 & 1.2 & 5.0 & 8.0 & 49.0 & 0.1 & 0.5 & 1.0 & 6.0 & 25.0 & 68.0 \\ \text { Male } & 0.2 & 0.5 & 1.0 & 6.0 & 14.0 & 33.6 & 0.2 & 0.5 & 2.0 & 6.0 & 12.5 & 46.0\end{array}$

Arsenic

$\begin{array}{lllllllllllll}\text { Female } & 0.04 & 0.08 & 0.11 & 0.23 & 0.29 & 0.53 & 0.06 & 0.09 & 0.12 & 0.14 & 0.20 & 0.48 \\ \text { Male } & 0.04 & 0.08 & 0.13 & 0.24 & 0.29 & 0.57 & 0.07 & 0.09 & 0.11 & 0.13 & 0.23 & 0.56\end{array}$

Barium

$\begin{array}{lllllllllllll}\text { Female } & 0.20 & 0.39 & 0.65 & 1.31 & 2.17 & 3.28 & 0.98 & 1.39 & 2.16 & 2.90 & 3.70 & 5.88 \\ \text { Male } & 0.25 & 0.37 & 0.61 & 1.19 & 2.10 & 7.96 & 1.06 & 1.50 & 2.35 & 3.27 & 4.62 & 7.13\end{array}$

Cadmium

$\begin{array}{lllllllllllll}\text { Female } & 0.01 & 0.01 & 0.02 & 0.02 & 0.03 & 0.06 & 0.01 & 0.03 & 0.06 & 0.10 & 0.15 & 0.51 \\ \text { Male } & 0.01 & 0.01 & 0.02 & 0.02 & 0.03 & 0.22 & 0.01 & 0.02 & 0.06 & 0.11 & 0.20 & 0.51\end{array}$

Chromium

$\begin{array}{lllllllllllll}\text { Female } & 0.27 & 0.33 & 0.56 & 0.92 & 2.38 & 70.2 & 0.30 & 0.45 & 0.75 & 2.19 & 5.35 & 21.8 \\ \text { Male } & 0.32 & 0.43 & 0.59 & 0.81 & 2.13 & 41.6 & 0.26 & 0.40 & 0.62 & 1.40 & 5.22 & 71.8\end{array}$


Supplementary Material (ESI) for Journal of Environmental Monitoring

This journal is (C) The Royal Society of Chemistry 2008

\begin{tabular}{|c|c|c|c|c|c|c|c|c|c|c|c|c|}
\hline \multirow{2}{*}{ Contaminant } & \multicolumn{6}{|l|}{ Bass } & \multicolumn{6}{|l|}{ Carp } \\
\hline & $10^{\text {th }}$ & $25^{\text {th }}$ & $50^{\text {th }}$ & $75^{\text {th }}$ & $90^{\text {th }}$ & $100^{\text {th }}$ & $10^{\text {th }}$ & $25^{\text {th }}$ & $50^{\text {th }}$ & $75^{\text {th }}$ & $90^{\text {th }}$ & $100^{\text {th }}$ \\
\hline \multicolumn{13}{|l|}{ Copper } \\
\hline Female & 0.27 & 0.42 & 0.51 & 0.64 & 0.80 & 1.01 & 0.87 & 0.95 & 1.07 & 1.30 & 1.55 & 3.32 \\
\hline Male & 0.29 & 0.41 & 0.50 & 0.58 & 0.67 & 1.20 & 0.82 & 0.90 & 1.08 & 1.25 & 1.48 & 3.92 \\
\hline \multicolumn{13}{|l|}{ Lead } \\
\hline Female & 0.01 & 0.02 & 0.04 & 0.06 & 0.13 & 0.83 & 0.03 & 0.06 & 0.10 & 0.14 & 0.19 & 0.45 \\
\hline Male & 0.01 & 0.02 & 0.03 & 0.06 & 0.13 & 0.49 & 0.02 & 0.05 & 0.09 & 0.15 & 0.26 & 0.69 \\
\hline \multicolumn{13}{|l|}{ Magnesium } \\
\hline Female & 293 & 329 & 382 & 487 & 537 & 634 & 260 & 290 & 322 & 366 & 410 & 530 \\
\hline Male & 301 & 339 & 417 & 500 & 573 & 673 & 265 & 287 & 329 & 380 & 443 & 513 \\
\hline \multicolumn{13}{|l|}{ Manganese } \\
\hline Female & 0.78 & 1.01 & 1.52 & 2.18 & 3.60 & 9.56 & 2.67 & 3.28 & 4.24 & 5.98 & 8.36 & 14.1 \\
\hline Male & 0.67 & 1.10 & 1.44 & 2.28 & 3.69 & 6.98 & 2.17 & 2.86 & 4.40 & 6.07 & 9.41 & 20.1 \\
\hline \multicolumn{13}{|l|}{ Mercury } \\
\hline Female & 0.10 & 0.12 & 0.21 & 0.35 & 0.47 & 0.69 & 0.03 & 0.07 & 0.10 & 0.14 & 0.16 & 0.31 \\
\hline Male & 0.07 & 0.10 & 0.21 & 0.26 & 0.46 & 0.78 & 0.04 & 0.07 & 0.11 & 0.14 & 0.17 & 0.34 \\
\hline \multicolumn{13}{|l|}{ Molybdenum } \\
\hline Female & 0.01 & 0.07 & 0.09 & 0.11 & 0.14 & 0.63 & 0.03 & 0.07 & 0.10 & 0.13 & 0.15 & 0.26 \\
\hline Male & 0.01 & 0.05 & 0.09 & 0.10 & 0.15 & 0.35 & 0.02 & 0.07 & 0.10 & 0.13 & 0.17 & 0.81 \\
\hline \multicolumn{13}{|l|}{ Nickel } \\
\hline Female & 0.13 & 0.15 & 0.29 & 0.57 & 0.93 & 3.29 & 0.13 & 0.16 & 0.29 & 0.50 & 1.03 & 2.98 \\
\hline Male & 0.13 & 0.16 & 0.30 & 0.68 & 0.90 & 2.48 & 0.12 & 0.15 & 0.28 & 0.52 & 0.95 & 5.59 \\
\hline \multicolumn{13}{|l|}{ Selenium } \\
\hline Female & 0.28 & 0.34 & 0.46 & 0.54 & 1.03 & 4.46 & 0.43 & 0.53 & 0.67 & 0.90 & 1.68 & 3.77 \\
\hline Male & 0.27 & 0.37 & 0.47 & 0.52 & 1.10 & 4.11 & 0.41 & 0.46 & 0.59 & 0.89 & 1.74 & 4.66 \\
\hline
\end{tabular}

Strontium

$\begin{array}{lllllllllllll}\text { Female } & 3.85 & 7.67 & 14.7 & 23.3 & 29.5 & 64.1 & 4.99 & 7.81 & 15.6 & 26.1 & 40.3 & 78.4 \\ \text { Male } & 3.96 & 6.50 & 13.8 & 25.9 & 40.0 & 87.7 & 5.36 & 8.97 & 15.7 & 27.0 & 42.2 & 74.8\end{array}$

Vanadium

$\begin{array}{lllllllllllll}\text { Female } & 0.03 & 0.06 & 0.09 & 0.11 & 0.14 & 0.39 & 0.09 & 0.10 & 0.13 & 0.20 & 0.28 & 0.54 \\ \text { Male } & 0.03 & 0.06 & 0.09 & 0.10 & 0.14 & 0.23 & 0.09 & 0.10 & 0.13 & 0.21 & 0.33 & 0.50\end{array}$

Zinc

$\begin{array}{lllllllllllll}\text { Female } & 11.5 & 13.5 & 15.5 & 18.3 & 22.5 & 29.1 & 55.6 & 65.0 & 76.6 & 89.0 & 100 & 135 \\ \text { Male } & 11.5 & 13.4 & 16.2 & 18.9 & 21.6 & 37.3 & 48.3 & 56.7 & 63.2 & 72.4 & 79.3 & 150\end{array}$

Censored values were represented by one half the limit of detection. ${ }^{\text {a }}$ not measured in samples from the Mississippi, Rio Grande, and Columbia River basins. 
Supplementary Material (ESI) for Journal of Environmental Monitoring

This journal is (C) The Royal Society of Chemistry 2008

1 Table S4. Cumulative frequency percentiles of biomarkers in individual fish.

\begin{tabular}{|c|c|c|c|c|c|c|c|c|c|c|c|c|}
\hline \multirow{2}{*}{ Endpoint } & \multicolumn{6}{|l|}{ Bass } & \multicolumn{6}{|l|}{ Carp } \\
\hline & $10^{\text {th }}$ & $25^{\text {th }}$ & $50^{\text {th }}$ & $75^{\text {th }}$ & $90^{\text {th }}$ & $100^{\text {th }}$ & $10^{\text {th }}$ & $25^{\text {th }}$ & $50^{\text {th }}$ & $75^{\text {th }}$ & $90^{\text {th }}$ & $100^{\text {th }}$ \\
\hline \multicolumn{13}{|c|}{ Length (mm) } \\
\hline Female & 269 & 305 & 351 & 414 & 470 & 614 & 387 & 444 & 505 & 576 & 657 & 1614 \\
\hline Male & 258 & 293 & 330 & 375 & 411 & 785 & 381 & 433 & 491 & 555 & 604 & 1489 \\
\hline \multicolumn{13}{|l|}{ Weight (g) } \\
\hline Female & 255 & 379 & 630 & 1035 & 1555 & 4700 & 795 & 1132 & 1698 & 2507 & 3900 & 9000 \\
\hline Male & 224 & 329 & 500 & 785 & 1030 & 2200 & 709 & 1038 & 1500 & 2125 & 2900 & 7545 \\
\hline
\end{tabular}

Condition factor

$\begin{array}{lllllllllllll}\text { Female } & 1.15 & 1.26 & 1.41 & 1.58 & 1.75 & 2.37 & 1.13 & 1.24 & 1.33 & 1.45 & 1.58 & 2.63 \\ \text { Male } & 1.12 & 1.24 & 1.39 & 1.57 & 1.74 & 3.53 & 1.09 & 1.19 & 1.28 & 1.39 & 1.51 & 3.28\end{array}$

Age (y)

$\begin{array}{lcccccccccccc}\begin{array}{l}\text { Female } \\ \text { Male }\end{array} & 2 & 2 & 3 & 4 & 6 & 12 & 2 & 3 & 5 & 8 & 23 & 62 \\ \text { Splenosomatic index (\%) } & 2 & 3 & 4 & 5 & 12 & 2 & 3 & 4 & 7 & 22 & 62 \\ \text { Female } & 0.06 & 0.07 & 0.10 & 0.15 & 0.22 & 1.03 & 0.14 & 0.18 & 0.23 & 0.30 & 0.40 & 3.94 \\ \text { Male } & 0.05 & 0.07 & 0.10 & 0.15 & 0.22 & 0.90 & 0.17 & 0.22 & 0.30 & 0.38 & 0.51 & 1.84\end{array}$

Hepatosomatic index (\%)

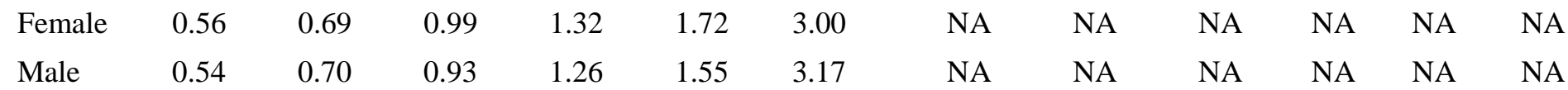

MA-A $\left(\mu \mathrm{m}^{2}\right)$

$\begin{array}{lllllllllllll}\text { Female } & 1150 & 1868 & 2891 & 4177 & 6019 & 19762 & 1424 & 2116 & 3271 & 4840 & 7027 & 36300\end{array}$

$\begin{array}{lllllllllllll}\text { Male } & 1138 & 1787 & 2907 & 4459 & 6268 & 18829 & 1308 & 1921 & 2860 & 4075 & 6253 & 25324\end{array}$

MA-\# (MA sq. $\mathrm{mm}^{-1}$ )

$\begin{array}{lllllllllllll}\text { Female } & 1.18 & 2.35 & 4.71 & 7.65 & 10.00 & 26.47 & 1.20 & 4.12 & 7.65 & 11.76 & 15.29 & 28.92 \\ \text { Male } & 0.63 & 2.40 & 4.71 & 7.65 & 10.00 & 18.24 & 1.76 & 5.29 & 8.82 & 13.53 & 17.65 & 32.35\end{array}$

MA-\% (\%)

$\begin{array}{lllllllllllll}\text { Female } & 0.17 & 0.55 & 1.41 & 2.82 & 4.33 & 11.24 & 0.30 & 1.21 & 2.54 & 4.45 & 6.57 & 23.94 \\ \text { Male } & 0.16 & 0.49 & 1.48 & 2.89 & 4.62 & 13.05 & 0.34 & 1.22 & 2.80 & 4.58 & 6.52 & 19.10\end{array}$

Health assessment index

$\begin{array}{lllllllllllll}\text { Female } & 0 & 30 & 60 & 90 & 120 & 200 & 0 & 0 & 30 & 40 & 70 & 160 \\ \text { Male } & 0 & 30 & 60 & 90 & 110 & 190 & 0 & 0 & 30 & 40 & 70 & 130\end{array}$

EROD (pmol min $\left.{ }^{-1} \mathrm{mg}^{-1}\right)$

$\begin{array}{lllllllllllll}\text { Female } & 4.32 & 7.87 & 16.80 & 37.72 & 62.90 & 232.8 & 0.15 & 0.62 & 1.56 & 3.78 & 10.73 & 203.2 \\ \text { Male } & 5.19 & 10.88 & 21.69 & 43.38 & 74.68 & 277.4 & 0.22 & 1.07 & 3.62 & 8.65 & 22.12 & 211.5\end{array}$

Gonadosomatic index (\%)

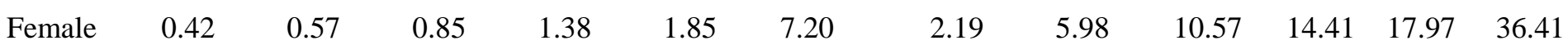


Supplementary Material (ESI) for Journal of Environmental Monitoring This journal is (C) The Royal Society of Chemistry 2008

\begin{tabular}{|c|c|c|c|c|c|c|c|c|c|c|c|c|}
\hline \multirow{2}{*}{ Endpoint } & \multicolumn{6}{|l|}{ Bass } & \multicolumn{6}{|c|}{ Carp } \\
\hline & $10^{\text {th }}$ & $25^{\text {th }}$ & $50^{\text {th }}$ & $75^{\text {th }}$ & $90^{\text {th }}$ & $100^{\text {th }}$ & $10^{\text {th }}$ & $25^{\text {th }}$ & $50^{\text {th }}$ & $75^{\text {th }}$ & $90^{\text {th }}$ & $100^{\text {th }}$ \\
\hline Male & 0.09 & 0.17 & 0.27 & 0.38 & 0.55 & 1.65 & 2.99 & 4.66 & 6.42 & 7.99 & 10.06 & 27.40 \\
\hline
\end{tabular}

Vitellogenin ( $\mathrm{mg} \mathrm{mL}^{-1}$ )

$\begin{array}{lcccccccccccc}\text { Female } & 0.0005 & 0.0005 & 0.047 & 0.905 & 3.347 & 77.92 & 0.097 & 0.997 & 2.149 & 3.244 & 4.993 & 17.32 \\ \text { Male } & 0.0005 & 0.0005 & 0.0005 & 0.001 & 0.008 & 3.147 & 0.0005 & 0.0005 & 0.002 & 0.003 & 0.016 & 2.645\end{array}$
$17 \beta$-estradiol $\left(\mathrm{pg} \mathrm{mL}^{-1}\right)^{\mathrm{a}}$

$\begin{array}{lcccccccccccc}\text { Female } & 249 & 385 & 587 & 899 & 1313 & 6330 & 351 & 569 & 991 & 1380 & 2117 & 5126 \\ \text { Male } & 158 & 229 & 343 & 498 & 669 & 1886 & 101 & 189 & 356 & 578 & 908 & 2918\end{array}$

11-ketotestosterone $\left(\mathrm{pg} \mathrm{mL}^{-1}\right)^{\mathrm{a}}$

\begin{tabular}{|c|c|c|c|c|c|c|c|c|c|c|c|c|}
\hline Female & 105 & 165 & 277 & 507 & 806 & 2203 & 117 & 183 & 314 & 568 & 923 & 2008 \\
\hline Male & 295 & 515 & 811 & 1257 & 1635 & 6040 & 220 & 424 & 921 & 1415 & 2298 & 8492 \\
\hline \multicolumn{13}{|l|}{$\mathrm{KT}_{\text {ratio }}{ }^{\mathrm{a}}$} \\
\hline Female & 0.79 & 1.38 & 2.17 & 3.50 & 5.95 & 27.76 & 1.06 & 1.78 & 2.93 & 4.63 & 6.89 & 32.52 \\
\hline Male & 0.16 & 0.25 & 0.42 & 0.70 & 1.29 & 16.37 & 0.13 & 0.22 & 0.40 & 0.69 & 1.32 & 19.33 \\
\hline
\end{tabular}

Oocyte atresia

$\begin{array}{llllllllllll}\text { Female } & 0 & 0 & 2 & 4 & 9 & 80 & 0 & 2 & 6 & 12 & 19\end{array}$

Censored EROD and vitellogenin values were represented by one half the limit of detection. NA, not applicable. ${ }^{\text {a }}$ not measured in samples from the Rio Grande and Columbia River basins. 